\title{
HILGARDIA
}

A Journal of Agricultural Science Publisbed by

the California Agricultural Experiment Station

\section{THE ECOLOGY OF SOLITARY BEES}

\author{
E. GORTON LINSLEY
}

UNIVERSITY OF CALIFORNIA - BERKELEY, CALIFORNIA 
Bees play an important and necessary role in the pollination of agricultural crops grown for fruit and seed and of forage and browse plants important in range management for production of both livestock and game animals. Nearly 20,000 different kinds of bees are now known, some, like the imported honey bee, the bumble bees, and the stingless bees of the tropics, are social and live together in colonies subject to manipulation and movement from place to place. However, by far the majority of bees are solitary, living in burrows in the ground, in wood, or in plant stems, where they store pollen and nectar as food for their young. Many of these take pollen only from certain kinds of plants and are very efficient pollinators of these. Others, like the honey bee, visit a wide variety of pollen plants, both native and introduced.

Although management procedures have been developed for certain crops in certain areas which permit the effective use of honey bees for increased production through better pollination, these are not universally applicable to our agriculture as a whole. For certain crops, both cultivated and wild, supplemental pollination is necessary. The development of management procedures which will permit increased utilization of native solitary bees and perhaps lead to the importation of foreign species native to the areas in which our agricultural crops originated, requires a detailed knowledge of the ecology, or environmental relationships, of these bees. This article is intended to review as briefly as possible, the current status of our knowledge of the subject and to indicate published papers in which various aspects may be pursued further. Prominence has been given to publications of the last fifteen years and to those which are most comprehensive and include references to earlier literature, Factors which appear to have had an influence in the economy, evolution, and survival of solitary bees have been especially emphasized. 


\section{CONTENTS}

Introduction . . . . . . . . . . . . . . . . . . . . . .543

Geographical distribution . . . . . . . . . . . . . . . . .544

Size of fauna. . . . . . . . . . . . . . . . . . . . . . . . . . 544

Ratio of genera to species . . . . . . . . . . . . . . . . 544

World distribution and regions of abundance . . . . . . . . . . 544

Continental distribution . . . . . . . . . . . . . . . . . 545

Bees of limited areas . . . . . . . . . . . . . . . . . . 546

Bees of arid regions . . . . . . . . . . . . . . . . . . 547

Bees and biotic areas. . . . . . . . . . . . . . . . . 547

Bees and plant communities. . . . . . . . . . . . . . . . 549

Dispersal of introduced species . . . . . . . . . . . . . . . 549

Dispersal of native species . . . . . . . . . . . . . . . . 551

General biology . . . . . . . . . . . . . . . . . . . . 552

Mating habits . . . . . . . . . . . . . . . . . . . 552

Selection of the nesting site . . . . . . . . . . . . . . . . 553

Nest construction . . . . . . . . . . . . . . . . . . . 554

Development and overwintering . . . . . . . . . . . . . . 556

Sleep . . . . . . . . . . . . . . . . . . . . . . .557

Food habits and flower relationships . . . . . . . . . . . . . . 557

Flower constancy . . . . . . . . . . . . . . . . . . . 558

Oligolectic bees . . . . . . . . . . . . . . . . . . . . . . . . . 559

Oligolecty and entomophilous flowers . . . . . . . . . . . . 563

Oligolecty in the tropics . . . . . . . . . . . . . . . . . 563

Adaptations associated with oligolecty . . . . . . . . . . . . . . 564

Ability to locate the appropriate pollen source . . . . . . . . . . 564

Seasonal synchronization with pollen source . . . . . . . . . . 565

Seasonal variation in activity in the tropics . . . . . . . . . . . 566

Diurnal synchronization with pollen source . . . . . . . . . . . 567

Morphological adaptations . . . . . . . . . . . . . . . .568

Origin and significance of oligolecty . . . . . . . . . . . . . . . . 569

Influence of physical factors on the flight of solitary bees . . . . . . . 571

Sunlight . . . . . . . . . . . . . . . . . . . 571

Wind . . . . . . . . . . . . . . . . . . . . . .571

Temperature . . . . . . . . . . . . . . . . . . . . . 572

Influence of physcial factors on bee populations . . . . . . . . . 574

Low temperature . . . . . . . . . . . . . . . . . . . 574

Unseasonal rainfall . . . . . . . . . . . . . . . . . . . 575

Parasites, predators, inquilines, and food depredators . . . . . . . 576

Organisms affecting the larvae. . . . . . . . . . . . . . . 576

Predators and parasites of adult bees . . . . . . . . . . . . . . 579

Role of parasites and predators in population control . . . . . . . . 581

The effects of parasitism on behavior of bees . . . . . . . . . . 584

Acknowledgments . . . . . . . . . . . . . . . . . . . . . . 584

Bibliography . . . . . . . . . . . . . . . . . . . 585 



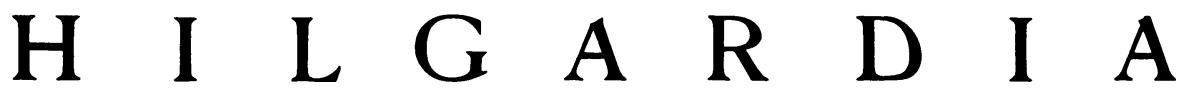 \\ A Journal of Agricultural Science Published by \\ the California Agricultural Experiment Station}

\begin{tabular}{lll}
\hline VoL. 27 & OCTOBER, 1958 & No. 19 \\
\hline
\end{tabular}

\section{THE ECOLOGY OF SOLITARY BEES'}

\section{E. GORTON LINSLEY'}

\section{INTRODUCTION}

MORE THAN 50 fruit and seed crops depend upon insect pollination for satisfactory yields. In recent years much progress has been made in the development of management procedures which make use of the introduced honey bee to increase agricultural production, particularly of legume seed crops grown in the southwestern United States. However, comparable management techniques have not been developed for the agricultural areas of northern and eastern United States, Canada, Scandinavia, northern Europe, and Russia (Åkerberg and Lesins, 1949; Peterson, 1954; Popov, 1951b, 1952c, 1956 ; Blagoveshchenskaia, 1954 ; Bohart, 1957; Hobbs, 1957 ; Medler, 1957) ${ }^{3}{ }^{3}$ As a result, considerable attention has been directed recently to the possibility of increasing the numbers of native species of bee pollinators (Bohart, 1947, 1957 ; Menke, 1952, 1954; Stephen, 1955 ; Blagoveshchenskaia, 1956; Medler, 1957; et al.) and suggestions have been made for improving the pattern of wild bee pollination by suitable introductions (Piper et al., 1914; Larkin, 1952; Hurd and Michener, 1955; Bohart, 1957; et al.). The success of such programs depends upon a sound knowledge of bee ecology (Cumber, 1953). Some practical aspects of ecology of social bees (Bombus) have recently been reviewed by Cumber (1953) and Medler (1957) and of stingless bees by Schwarz (1948).

The present review is concerned with the environmental relationships of solitary bees, including ethological features of importance in their economy, survival, and evolution. No attempt has been made to develop historical aspects or floral ecology. In some cases only the later and more comprehensive papers have been cited, especially when these include bibliographical references to the earlier literature. Special attention has also been given to articles published in the last fifteen years, many of which have not yet been reviewed or commented upon. However, even within these limits, space will still not permit reference to hundreds of papers which have contributed to our knowledge of bee ecology as defined above. For convenience of reference, the taxonomic classification followed is essentially that of Michener $(1944 a)$.

\footnotetext{
${ }^{1}$ The survey of the literature pertaining to this review was completed in June, 1957. Received for publication November 21, 1957.

${ }^{2}$ Professor of Entomology and Entomologist in the Experiment Station, Berkeley.

"See "Bibliography" for citations referred to in the text by author and date.
} 


\section{GEOGRAPHICAL DISTRIBUTION}

Size of Fauna. The bee fauna of the world is very large. Precise figures are not available but thirty-five years ago Friese (1923) estimated that bees represented more than one fourth $(12,000 \mathrm{spp}$.) of the then known Hymenoptera (46,000 spp.). More recently, Stevens (1948) estimated that the total must be in the vicinity of 15,000; Michener (1955b) at about 19,000.

Ratio of Genera to Species. A characteristic of bees as a group is that the large numbers of species fall into relatively few genera. Friese (1923) recognized only 100 genera for an estimated 12,000 species. The most recent catalogue of bees for a major region of the world (Muesebeck, Krombein, and Townes, 1951) lists 99 genera and 3,287 species and subspecies in the portion of America lying north of the Mexican boundary. Of these, seven genera and about 400 species are social or semisocial and 26 genera and about 400 species are parasitic, leaving 66 genera and nearly 2,500 species of solitary nesting bees. Among the larger of these are Andrena (500+ spp.), Perdita (nearly 300 spp.), Megachile and Melissodes (each nearly 150 spp.), and Osmia (100+ spp.).

World Distribution and Regions of Abundance. Generally speaking, solitary bees are found throughout the world from the Arctic Circle to Tierra del Fuego and Tasmania, wherever flowering plants grow and suitable conditions exist for nesting. However, social bees of the genus Bombus are dominant in the higher latitudes $\left(60^{\circ}\right.$ to $\left.65^{\circ}\right)$ of Scandinavia, Siberia, Alaska, and Canada (Friese, 1902; Sladen, 1919) and some species are circumpolar, differentiating subspecifically in various regions (Friese, 1935). Certain colletids (Hylaeus) and megachilids (Osmia, Hoplitis, Heriades and Megachile) which do not nest in the ground occur far to the north, and so do a few of the ground-nesting types (Andrena, Melitta) (Zetterstedt, 1838; Smith, 1853; Friese 1902). However, of 81 species or subspecies of bees considered by Friese (1902) to be arctic forms, only 46 (57 per cent) are solitary bees or their parasitic derivatives; the remainder (43 per cent) are Bombus (and Psithyrus). Thirty species of bees are now known for Alaska (Hurd, in litt.). Sixteen of these are Bombus (or Psithyrus), 11 are megachilids, three are Andrena, of which A. clarkella (Kirby) is Holarctic in distribution. In the Antipodes, the Chilean Bombus dahlbomii GuérinMéneville and certain halictine species penetrate farthest southward (Malyshev, 1936).

Social bees also thrive in tropical regions (e.g. Trigona, Melipona), and of 353 species of bees recorded for Panamá by Michener (1954), 73 (21 per cent) are social Apidae (and parasitic derivatives). By contrast, only six species of Bombus are represented among the 439 species of bees now known from the semiarid locality of Riverside, California (Timberlake, in litt.). Damp tropical forests are generally unfavorable for ground-nesting bees and in regions of excessive humidity the endemic bees nest in a dry or protected substrate, as Xylocopa, Megachile, Trachusa (Malyshev, 1936). The greatest abundance of solitary bees is in the warm arid sections of the world having a semidesert character, especially western North America, Turkestan and adjacent regions, the Mediterranean basin, parts of South Africa, Australia, and western South America (Malyshev, 1936; Michener, 
1940). Mountainous areas with moderate rainfall also offer varied floras and well-drained soil favorable to nesting. They commonly support abundant bee faunas.

Continental Distribution. Several genera of bees are more or less worldwide in distribution and have retained a remarkable degree of homogeneity in the course of their history. Such genera include Hylaeus, Colletes, Halictus (and Sphecodes), Megachile, and, to a slightly lesser extent, Anthophora. Others, such as Nomia, Lithurge, Ceratina, and Xylocopa, are more or less abundant and diversified in the warmer parts of both hemispheres. One genus, Hesperapis, has been found only in the arid regions of western North America and South Africa (Cockerell, 1936). A number of northern genera are primarily Holaretic, barely invading or poorly represented in the Southern Hemisphere. Included here are Andrena (and Nomada), Panurginus, Macropis, Dufourea, Osmia, Chelostoma, Dianthidium. Species represented in both the Old World and New World include at least two of Andrena, several each of Osmia and Megachile, and Anthophora (Clisodon) furcata (Panzer).

The southern continents have derived or retained certain large groups of their own, as the primitive Paracolletini. South America is characterized by the diphaglossine and chilicoline colletids, including Ptiloglossa, the large fauna of exomalopsine, emphorine and centrine Anthophorinae, the diversity of certain groups of Halictidae (as Augochlora), and the absence of the Melittidae. Africa is noted for the colletid genus Scrapter, the panurgines Poecilomelitta, Meliturgula, Mermiglossa, the halictine Thrincostoma, the xylocopine Allodape, and the Fideliidae, ${ }^{4}$ and Australia, not only for the variety of genera and species of primitive, short and obtuse-tongued, skinmaking bees (Colletidae) and the xylocopine genus Lestis, but also for the absence of certain groups, as the Panurginae. The New Zealand bee fauna is small and little known (Heine, 1937; Thomson, 1927) but has been supplemented by the successful introduction of bumble bees (Armstrong, 1883; Farr, 1886, et al.). As might be expected, the African bee fauna (Friese, 1909; Cockerell, 1936; Arnold, 1947) shows a definite Palearctic influence. It also exhibits numerous affinities with the Orient, as indicated by such groups as Mesotrichia, Crocisa, and Nomioides which occur also in southeastern Asia and Australia but are absent from the Western Hemisphere. The last is considered by Cockerell (1936) to be a halictine counterpart of the American panurgine genus Perdita, the species of which are similarly small and brightly colored. Habralictus is a Neotropical equivalent.

As might be expected, the larger genera of bees inhabiting Europe, Asia, and North America have rather broad and simple distributions with northern types dominating the northern continents, even south of the Himalaya Mountains (Bingham, 1897). Michener (1940) has characterized the situation in North America as follows: almost all bees north of approximately the Canadian border are northern types, those of the tropies are nearly all Neotropical, while those of intermediate regions, including most of the United States and the Mexican plateau, consist of a mixture of the two, the southern

\footnotetext{
${ }^{4}$ One species in this family has, however, been described recently from Chile (Moure and Michener, 1955).
} 
forms decreasing toward the north, the northern toward the south. This generalized picture is nearly unmodified in the eastern half of the United States, where almost unaltered elements from both regions mingle, but in the west it is modified not only by varying topographic and climatic conditions which permit boreal faunas to extend southward along the mountain ranges, but also by the warm southern interior, contiguous with the climatically similar Mexican plateau, and forming with it a distinctive subregion, the Sonoran, combining arid phases of the Nearctic and Neotropical biotic regions, the Nearctic influence predominating within the United States.

The role of Panamá in the zoogeography of bees of the Western Hemisphere has been graphically described by Michener (1954). He emphasizes not only that the area must have been traversed by most of the groups of animals that have passed between the two continents, but also that groups are apparently still in the process of spreading along the Isthmus. Several Nearctic or Holaretic genera of bees (e.g., Andrena, Calliopsis, and Heriades) reach the southernmost limits of their known range near the Canal Zone. Since no major physiographic or climatic barriers exist between the southern limits of these groups and the broad expanses of the South American continent, Michener regards it as probable that these groups are recent arrivals, extending their way southward. Michener also states that a number of groups are absent from the lowlands of the Canal Zone region but occur at higher altitudes to the south and the north. Examples are several species of Bombus in the higher altitudes of middle America, including the mountains of Chiriquí Province, which are absent from the rest of Panamá, where altitudes are low, but reappear again at moderate altitudes in South America, and do not appear to be even subspecifically distinct. As a result, it is assumed that quite recently conditions similar to those of the 4,000-foot level of the Chiriquí area, extended more or less continuously from Chiriquí to Colombia.

Bees of Limited Areas. A further characteristic of bees is that within a given region a relatively small area may support a very large percentage of the known species. Although only some 3,200 species of bees have been recorded for America, north of Mexico, 439 species $^{5}$ have been collected at Riverside, California (Timberlake, in litt.), and nearly 300 at Carlinville, Illinois (Robertson, 1928). Hurd and Michener (1955) state that of 154 species in eight genera of North American megachiline bees studied by them, 116 species have been found in California and eight more probably occur, representing nearly 90 per cent of the species known from the Western Hemisphere. Likewise, of the 64 known species of Dufourea, 54 are found in California (G. E. Bohart, in litt.). Apparently bees are less numerous in southeastern United States where Michener (1947b) found 104 species near Hattiesburg, Mississippi, Graenicher (1930) only 65 in southern Florida. The relatively few genera of solitary bees, the relatively large number of species contained in most of these genera, and the high percentage of these species that can be found in certain areas suggest that the bees are a highly adaptive group and that presumably the reasons for their evolutionary success are to be found in their ecology.

${ }^{5} 117$ of these represent undescribed species or subspecies. 
Bees of Arid Regions. As has been emphasized above, the desert and arid areas of the world are particularly rich in bees, and the faunas concerned have had complicated derivations. With reference to North America, Michener (1940) has stated that the bees of the desert areas may be arbitrarily divided into two overlapping groups based upon their season of flight and the nature of the plants upon which they feed. The first of these consists of genera which, in the desert, fly primarily in the spring and are dependent upon the flowers of herbaceous mesophytes which grow and bloom during the short period when the desert is relatively moist. These are primarily Holarctic types (e.g. Andrena, Dufourea, and Tetralonia). The second group consists of genera which visit the flowers of the characteristic xerophytes, such as Larrea, Prosopis, and Cercidium, that bloom not only in the spring but also later in the year. The nearest relatives of these forms are Neotropical (e.g. Centris, Ericrocis, Protoxaea and apparently Perdita), or representatives of nearly cosmopolitan genera (e.g. Halictus and Megachile). Michener points out that there is scarcely a genus of bees every species of which may be unquestionably placed in one or the other of these groups, yet the division is quite evident.

In discussing a more restricted group (certain megachilid bees), Michener $(1944 b)$ has stated that with the exception of four groups, the American osmiine bees are northern and montane forms, rare in the deserts and virtually absent in the neotropics. The four exceptions, independently derived from northern forms, are characteristic of a zone in which they probably arose along the western margin of the desert of central and southern California. ${ }^{6}$ Three of the groups are largely confined to this zone. The fourth, Ashmeadiella, has a broader range, covering most of North America, but is divisible into several subgenera, the distribution of which forms concentric areas whose common center is in the same region.

One of the most fascinating of zoogeographical questions involves the plant and insect groups common to the deserts of North and South America. On this subject, Michener (1954) has remarked that at least scattered desert areas must have once extended through Central and South America, presumably near the western shores. He notes that at the present time some of the promontories extending into the Pacific in the region of the Canal Zone exhibit quite xeric characteristics. Instead of being covered with jungle or grasslands (savanna), they support a tangle of large bushes and small trees (including mesquite, Prosopis chilensis) among which grow cactus plants. These localities are by no means deserts, but their vegetation suggests that they might become deserts if higher mountains or other factors reduced the rainfall of the Pacific side of Panamá.

Bees and Biotic Areas. Graenicher (1935) has discussed the distribution of bees in relation to biotic areas in Wisconsin, and Cockerell (1893) refers to the vertical distribution of bee species in a mountainous locality in Colorado. An informative analysis of bee distribution in relation to biotic areas has been provided by Hurd and Michener (1955) in their study of some megachiline bees in California. Making use of certain biotic areas outlined

\footnotetext{
${ }^{6}$ Some of these groups have since been shown to have a wider distribution (Michener, $1951 a$ ) than was at first believed to be the case, but these generalizations appear to be basically valid.
} 


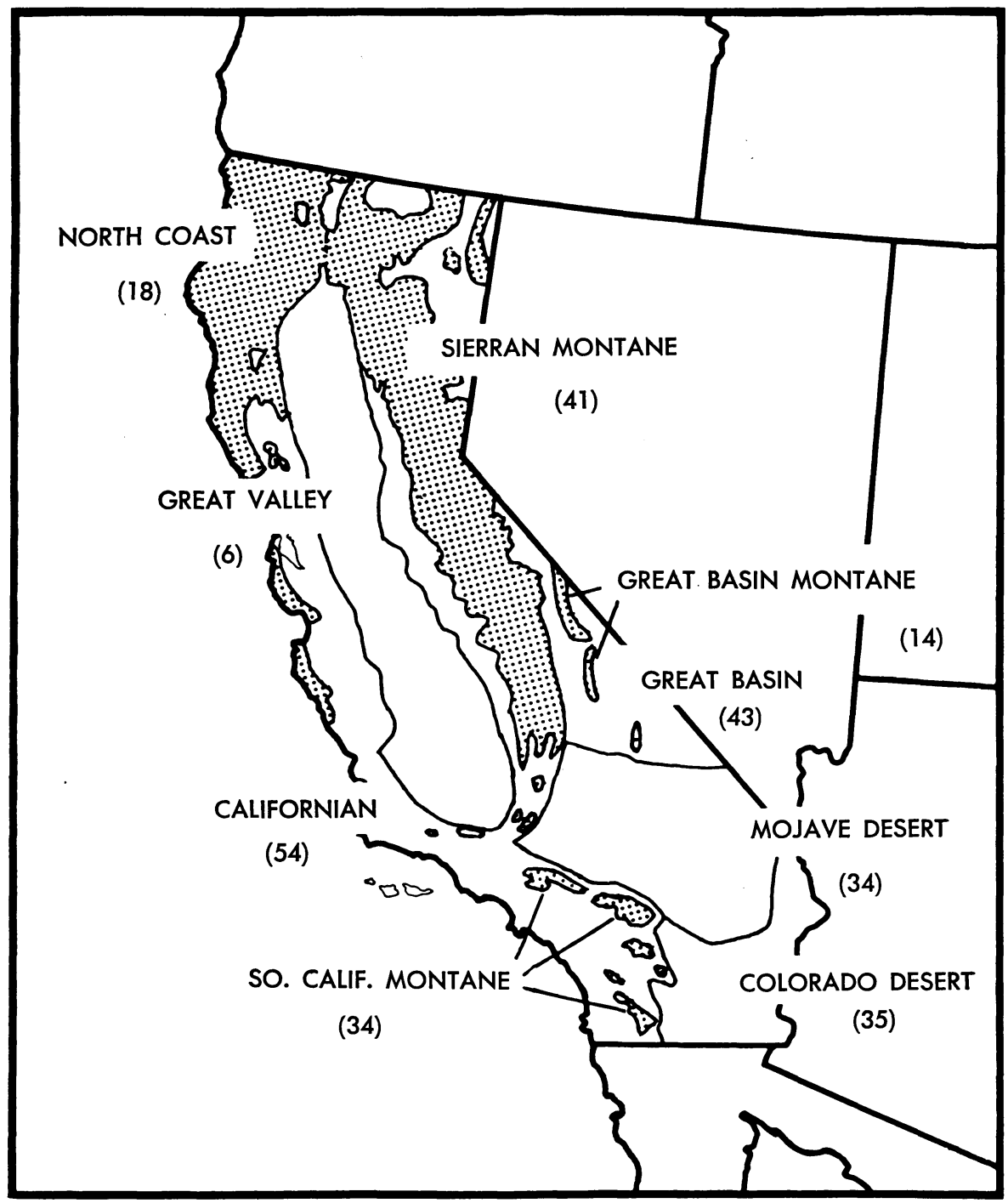

Fig. 1. Boreal (stippled) and Austral (white) areas of California showing biotic subdivisions occupied by the megachiline bees listed in table 1 . Numbers indicate the number of species found in each district (after Hurd and Michener, 1955).

by Miller (1951), the number of species in each genus or subgenus occurring in these areas was tabulated (table 1) and recorded on a map (fig. 1). Their data reveal that some of the groups are wide ranging (e.g., Ashmeadiella s. str., Alcidamea), others more restricted (e.g., Hoplitina, Acrosmia, Eremosmia). However, no species were found in all the areas, many were restricted to specific areas. Commonly some species were entirely or principally found in the areas classed as boreal, or entirely or principally austral, although sometimes (e.g., Anthocopa triodonta, Cockerell) they straddled 
this line. More important, perhaps, the austral species (presumably derived from boreal groups) are more abundant than the boreal. This is in agreement with the generalization expressed above that solitary bees as a group appear to find warmer and drier regions more favorable than warmer and moister or cooler and moister regions. Also, from these and other studies it seems probable that most bee distributions are determined more by broad climatic factors than by biotic areas.

Bees and Plant Communities. Graenicher (1930) has briefly discussed bees and plant communities in the Miami region of Florida, but without drawing any generally applicable conclusions. Pearson (1933) in a study of the ecological relations of bees in the Chicago region concluded that although there is a frequent preference for some community or community type, bees are to be thought of as "following" the flowers and as being probably secondarily adapted to the communities which they are thus led to frequent. He was only occasionally able to indicate a bee as a visitor to only two or three communities, yet he considered it feasible to present lists of bees to be expected in the various communities (table 2) at the proper seasons. He also concluded that certain families of bees are more characteristic of a given community than of another, the social bees (Apidae) and semisocial bees (Halictidae) being the least so. A broad study of bees in relation to the entomophilous vegetation and plant associations has been made by Popov (1952) in the State Forest region of Mt. VishnevayaCaspian Sea. More than 21,500 bees of 120 to 140 species were collected and classified according to 120 kinds of vegetation. Meadowland was richest in numbers of individuals and diversity of species, with wild or wastelands and forests least so. Species adapted to steppe vegetation were few and most of these penetrated into wastelands or other categories. Bees of the forest fringe area, although abundant, mainly involved species widely seattered through other zones or plant communities.

Dispersal of Introduced Species. Certain bees, especially those which nest in wood or plant stems, are subject to transport by man and have been accidentally introduced into various regions. Moure (1943) has reported the introduction and spread in Brazil of the European species Anthidium manicum (Linnaeus) which nests in wood, including furniture, and is now common in the state of São Paulo, visiting principally flowers of Leonurus and Anthirrhinum. All of the Hawaiian bees except those of the genus Nesoprosopis appear to have been introduced accidentally by man, including five species of Megachile and one each of Xylocopa and Lithurge (Williams, 1927). According to Timberlake (in litt.), one of the species of Megachile was probably introduced by the Polynesian people. Andrena wilkella (Kirby) appears to have been introduced into eastern North America where it is now common but is notably lacking from the local lists of fifty years ago and more. The best documented account of the establishment and spread of old World species introduced into North America has been provided by Hurd (1954) for three species of the megachiline subgenus Eutricharea which have been established along the Atlantic seaboard, in the Great Plains states and in California. The species are not thought to be oligolectic, yet half of the plant species visited in the Great Plains area and half of those in Cali- 


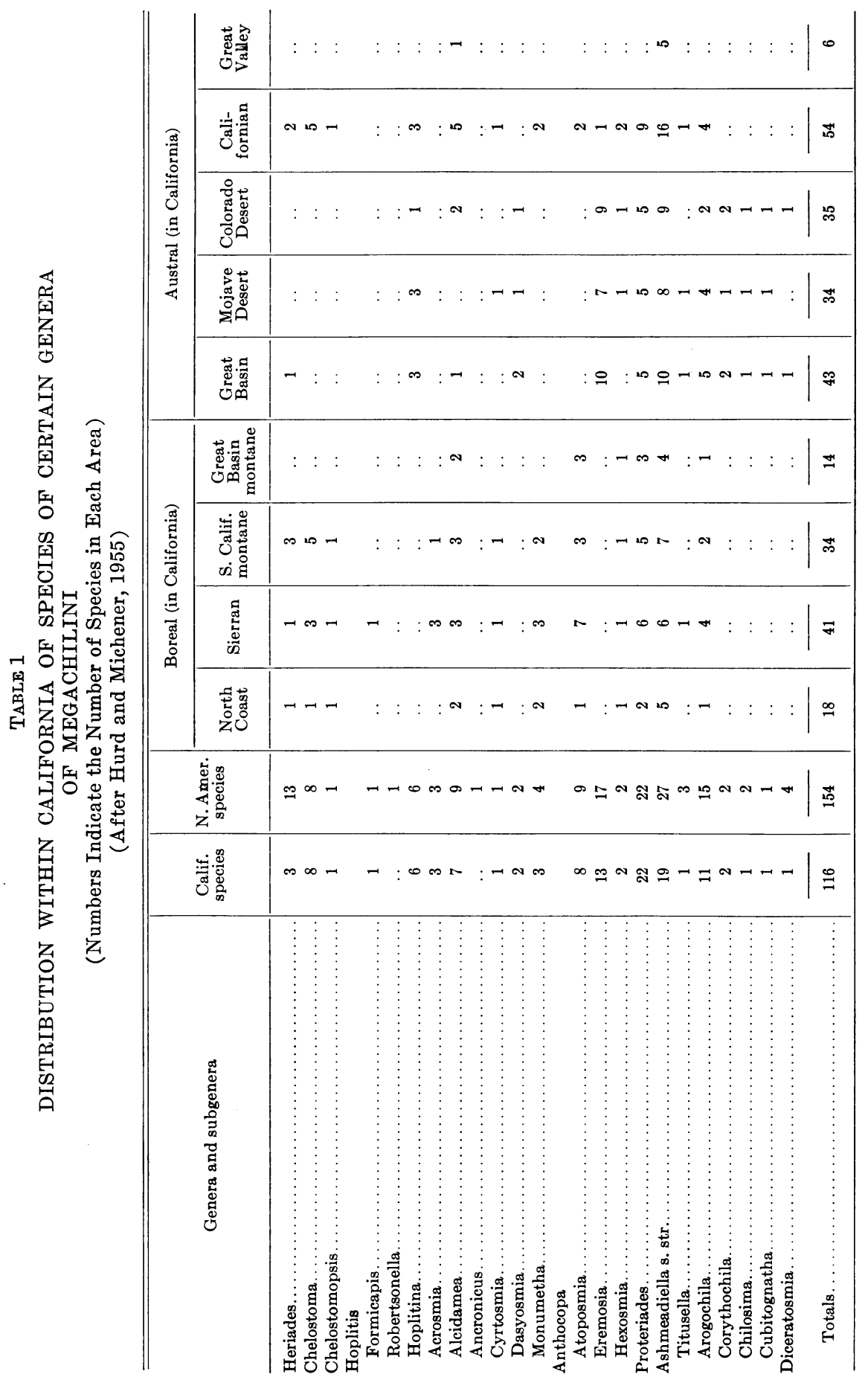


TABLE 2

PREDICTIONS OF THE OCCURRENCE OF BEES IN VARIOUS PLANT COMMUNITIES IN THE CHICAGO AREA BASED UPON FLOWER RELATIONSHIPS OBSERVED BY ROBERTSON AT CARLINVILLE, ILLINOIS

(AFTER PEARSON, 1933)

\begin{tabular}{|c|c|c|c|c|c|}
\hline Community & $\begin{array}{l}\text { No. of bee } \\
\text { species } \\
\text { predicted }\end{array}$ & $\begin{array}{l}\text { No. abun- } \\
\text { dant or } \\
\text { frequent }\end{array}$ & $\begin{array}{l}\text { No. of } \\
\text { flower } \\
\text { species } \\
\text { visited }\end{array}$ & $\begin{array}{c}\text { Ratio of } \\
\text { flowers } \\
\text { to bee } \\
\text { species }\end{array}$ & $\begin{array}{l}\text { No. of } \\
\text { flower bee } \\
\text { species } \\
\text { visits }\end{array}$ \\
\hline \multicolumn{6}{|l|}{ Sand dune and upland associations } \\
\hline Beach...... & 0 & 0 & 0 & & 0 \\
\hline Fore-dune. & 46 & 9 & 4 & $1-11.5$ & 61 \\
\hline Cottonwood. & 102 & 38 & 10 & $1-10.2$ & 159 \\
\hline Pine dune... & 153 & 71 & 18 & $1-8.5$ & 344 \\
\hline Black oak... & 195 & 90 & 47 & $1-4.15$ & 668 \\
\hline Mesophytic oak forest. . & 179 & 86 & 56 & $1-3.19$ & 854 \\
\hline Climax Mesophytic forest. & 130 & 49 & 47 & $1-2.76$ & 591 \\
\hline Sandy swamp.............. & 63 & 12 & 12 & $1-5.25$ & 119 \\
\hline \multicolumn{6}{|l|}{ Prairie association } \\
\hline Low prairie..... & 153 & 64 & 44 & $1-3.47$ & 615 \\
\hline High prairie.... & 222 & 131 & 73 & $1-3.04$ & 1364 \\
\hline \multicolumn{6}{|l|}{ Aquatic associations } \\
\hline Submerged aquatics. . & 35 & 11 & 2 & $1-17.5$ & 36 \\
\hline Floating-leaved aquatics. & 20 & 9 & 3 & $1-6.66$ & 27 \\
\hline Emergent aquatics........ & 115 & 57 & 13 & $1-8.84$ & 283 \\
\hline Reed swamp........... & 0 & 0 & 0 & $\ldots .01$ & 0 \\
\hline Sedge swamp...... & 122 & 39 & 25 & $1-4.88$ & 383 \\
\hline \multicolumn{6}{|l|}{ Peat bog associations } \\
\hline Sedge............. & 90 & 22 & 10 & $1-9.0$ & 153 \\
\hline Xerophytic shrub... & 11 & 3 & 3 & $1-3.66$ & 12 \\
\hline Tamarack............... & 52 & 8 & 3 & $1-17.3$ & 56 \\
\hline Pine-birch forest....... & 69 & 21 & 4 & $.1-17.25$ & 94 \\
\hline Rock ravine associations. & 43 & 9 & 5 & $1-8.6$ & 67 \\
\hline River cliff associations... & 189 & 103 & 34 & $1-5.56$ & 705 \\
\hline Flood-plain associations... & 223 & 137 & 120 & $1-1.85$ & 1698 \\
\hline Lake cliff associations..... & 150 & 63 & 18 & $1-8.31$ & 337 \\
\hline Totals. & 2362 & 1032 & 551 & $1-4.28$ & 8616 \\
\hline
\end{tabular}

fornia are of Old World origin. Unfortunately, data on the ecological impact of introduced solitary bees are virtually lacking. However, Pearson (1933) says that the honey bee in North America appears to exert an influence upon native bees, which is visible to any student of the native species. $\mathrm{He}$ states that it is so efficient a collector of pollen and nectar and so ubiquitous, that there can be no question but what its inroads cause a serious diminution in the food supply of native bees, particularly in unfavorable seasons.

Dispersal of Native Species. The development of agriculture has undoubtedly had a profound influence on the distribution of native bees. The cultivation of squash in North America has greatly increased the range of species of Xenoglossa and Peponapis (Linsley, MacSwain, and Smith, 1956a; Fronk and Slater, 1956), which were formerly limited to areas of native gourds such as Cucurbita foetidissima. Likewise, the world-wide cultivation of alfalfa (Medicago sativa) has undoubtedly increased the distribution of the local native bees associated with legumes or preadapted to make use of this plant [e.g. Nomia melanderi Cockerell, Melitturga clavicornis (La- 
treille) ]. Unfortunately, precise data are lacking and we can only speculate as to what must have happened in such cases. On the other hand, many agricultural practices also are known to be disadvantageous to native bees (Bohart, 1955) and have reduced their range by destruction of nesting sites.

Timberlake (in litt.) reports that the common Lasioglossum stultum (Cresson) of eastern North America has become established at Riverside, California, since he first began collecting there in 1924, and is now abundant. Since this species is also found in the Old World, it may have been introduced. Although the mechanism of dispersal in this case is not clear, Lasioglossum spp. are commmonly found in moving automobiles (G. E. Bohart, in litt.). In fact, the social halictines in general are widespread in distribution. For instance, the common Halictus ligatus Say, of southern Canada and the United States occurs at least as far south as Colombia. Among carpenter bees of the genus Xylocopa, recent extensions of range have been reported both in Europe (Haan, 1952; van Lith, 1955) and North America (Hurd, $1955 ; 1956)$. Hurd (1956) attributes local range extensions of $X$. tabaniformis orpifex Smith to the creation of suitable nesting sites in the form of structural timbers in areas previously unavailable to the bee. Westward extension of the range of an eastern North American ground-nesting solitary bee, Melissodes bimaculata Lepeletier, has been recorded by Cockerell (1938).

\section{GENERAL BIOLOGY}

The natural history and nesting habits of solitary bees fascinated many early students of insect biology (e.g. Réaumur, 1734-1742 ; Fabre, 1879 1907), and studies of this phase of bee biology reached a high level in the works of Malyshev (1936). Life history studies are still needed as many lacunae remain to be filled. However, such studies are most useful when written from the comparative, phylogenetic, or ecological points of view (Linsley, MacSwain, and Smith, 1952c; Michener, 1953a; Michener, et al., 1955). The following summary relates to various phases of the natural history of bees which have ecological implications. Much of the information included is treated in greater detail by Pérez (1889) ; Friese $(1891,1923)$; Ferton (1923) ; Bischoff (1927) ; Nielson (1934) ; Caullery (1942) ; Michener (1944a) ; Hardouin (1948) ; Bohart (1953); Grandi (1951) ; and especially Malyshev (1936).

Mating Habits. In order to function as an isolating mechanism mating habits must be highly specific in a group as numerous in species as the bees. This appears to be generally the case. Some of the species which nest gregariously (e.g. certain anthophorines and panurgines), mate over the nesting site which is patrolled by the males while the females are active. In a few instances (e.g. some Andrena and Paracolletes), mating may take place in the burrow. Bohart (1950) has reported a situation in which males of several species of halictines were mating and attempting mating, sometimes indiscriminately, with females feeding on fermenting juices of watermelon. In most cases, however, mating occurs at or in the vicinity of flowers which the female is visiting for pollen, although in Nomia melanderi Cockerell it takes place both at the nesting site and at flowers. Males of this species have 
most success in copulating with freshly emerged females whose wings are not strong enough for full flight, but they are sometimes so abundant on alfalfa flowers as to force females to forage half a mile away (G. E. Bohart, in litt.). In species with highly restricted pollen sources, male flower response may be as specific as that of the female (e.g. Diadasia). In species with a variety of acceptable pollen sources the males may have to range widely in search of females and the pattern is far less restricted (e.g. certain nongregarious Anthophora). Males of certain species of Andrena apparently patrol hedgerows and nonblossoming shrubs (Perkins, 1919), and Rayment (1935) records male flights of Paracolletes facialis Cockerell about tips of Leucopogon one to two weeks before the plants bloom. Rayment also reports the males of Australian Trichocolletes at Hardenbergia and Hovea, the females at Daviesia spp.

Copulation is usually very brief and difficult to observe, often lasting only seconds. However, in the Panurginae it is prolonged, and mating pairs are commonly encountered (Robertson, 1922 ; Rozen, 1958). In Nomadopsis males of some species seek the female at the nesting site and may ride to the flower site attached to her (Rozen, 1958); in others the reverse is true.

A phenomenon associated with mating in solitary bees is proterandry (Müller, 1882) ; Demoll, 1908; Robertson, 1918, 1930) or the emergence of males in advance of the females, presumably to assure immediate fertilization. In certain groups which arrange their cells end to end (e.g. Osmia), males sometimes develop in the outermost cells to facilitate this timing. Although there is no doubt of the early emergence of males of certain species of bees, most data gathered in relation to proterandry have been taken from observations or collections made at flowers. Actual emergence data from the nesting site of Andrena erythronii Robertson does not support the conclusion that it is proterandrous in emergence, although the males precede the females in activity about the flowers (Michener and Rettenmeyer, 1956). However, proterandry is definite in Nomia melanderi Cockerell and is reflected in earlier pupation and transformation in the cells as well as in flight (G. E. Bohart, in litt.). In any event, the male season in solitary bees is usually considerably shorter than that of the female (Robertson, 1918; 1930).

Robertson (1922) in discussing proterandry in the Panurginae considered that all of the local species were proterandrous but pointed out that the males apparently precede the females by so few days that this was difficult to establish, and his flower records yielded nearly twice as many females as males.

Selection of the Nesting Site. The most important limiting factors involved in suitable nesting sites appear to be a satisfactory substrate, proximity of appropriate sources of pollen and nectar, and in some cases nearness to water (e.g. many anthophorines) or plants with certain types of leaves, fibers, mud, or resins (e.g., most megachilids). However, a great many solitary bees return to the site from which they emerged and construct their nests near those of their parents. Among ground-nesting forms this sometimes ultimately results in extensive aggregations involving thousands of nests (e.g. certain Andrena, Dasypoda, Anthophora, and Nomia), but usually 
the resultant groups are much smaller, and gregarious tendencies less well marked (Malyshev, 1936). In some cases, however, new sites may receive populations of 100,000 females or more within a few days in Nomia melanderi Cockerell and Nomadopsis scutellaris (Fowler) (G. E. Bohart, in litt.).

Most solitary bees nest in the ground. Depending upon the species, a preference may be exhibited for loose or hard-packed, sandy, or clay-like soil. Most bees avoid areas which are gravelly or rocky or where the vegetation, especially grass, is dense, but some regularly select rocky soil. Many prefer open-bare ground (e.g., many Nomia), others the edges of woods or glades (e.g., some Andrena, Panurgus, Systropha). Still others nest under the protection of a dead leaf, stone, or piece of wood. Callomelitta picta Smith constructs its burrows in punky wood instead of soil (Rayment, 1935). Nearly all prefer fairly well-drained sites and certain species of Anthophora and Colletes regularly select banks (including man-made walls of mud and adobe bricks). Megalopta ipomoeae Schrottky, a nocturnal bee, has been found nesting in moist ground in the semidarkness of a tropical forest (Jörgensen, 1912; Malyshev, 1936). Various other bees also nest in moist soil but avoid areas with poor surface drainage (Bohart, 1955).

Among the groups which regularly nest in plant materials (many Hylaeus, Ceratina, Xylocopa, most smaller Megachilini, but including some Megachile), some utilize plant stems (as bramble, raspberry, teasel, mullein, bamboo, et cetera), others burrow into the pith or soft heartwood of dead twigs and branches (as elderberry, maple, ash, et cetera), a few nest in galls, cones, or fruits. In most cases an existing hole or crack is necessary to provide access into the stem or branch, and the bees then excavate the softer materials. Most species of Xylocopa and the anthophorine subgenus Clisodon gnaw out tunnels in solid wood.

Preëxisting cavities are utilized by many megachilids and species of Hylaeus and these may include beetle burrows in wood or bark, deserted nests of anthophorine bees and mud wasps, snail shells, or such man-made cavities as nail holes, key holes, et cetera. A few bees (Chalicodoma, Euglossa) construct their nests in exposed or only partially enclosed areas such as large cavities in stones, under overhanging cliffs, beneath roofs or buildings, et cetera. Species of Dianthidium attach their nests to exposed rocks or plant stems.

Nest Construction. Malyshev (1936) has given a full account of the preparation of the nesting site by various solitary bees. Certain features having special ecological significance should be mentioned here. Many groundnesting species pile the excavated soil from their burrow about the entrance in a characteristic hillock or tumulus. These tumuli are often quite conspicuous, and, incidentally, provide recognition landmarks for parasites and predators, especially bombyliid flies which flick their eggs into the entrance. Others (certain Nomia, Anthophora, Diadasia, Eucera, et cetera) construct an entrance tube or turret. These vary greatly in form and structure and have been regarded by some as a means of protecting the entrance from rain or to prevent certain types of parasitism. However, in many species the turrets have dorsal gaps which would seem to minimize any such functions. Since turrets are most common among groups of bees in which 
gregarious nesting is prevalent, they may have some social significance. Emlen (1952) associates the retort-shaped nest of the cliff swallow with intense local territorialism.

The main shaft also varies in length and in shape from species to species. Those forms which nest in ground covered by vegetation (e.g. Xenoglossa fulva Smith) apparently dig deep to avoid plant roots. Those that nest in sandy, well-drained desert soils (e.g. Andrena mojavensis Linsley and MacSwain) apparently sink a deep shaft to the appropriate moisture level. The number and arrangement of cells are also variable. Some colletids, the xyclocopines, and most of the anthophorines and megachilids place the cells end to end in a regular series and, except for the first, emerging bees must escape through the cell above. Some colletids, the andrenids, dufourines, and melittids construct separate cells at the end of short tunnels off the main shaft.

The cells may be formed by hollowing out the end of a burrow or, as in many anthophorines, they may be built into the excavated cavities and can be removed intact during excavation. Various intermediate conditions also exist and have been fuHy discussed by Malyshev (1936). The cells and sometimes the tunnels of the colletids are lined with a thin transparent cellophane-like material. In the more primitive colletids the cells are usually separate, at the ends of individual tunnels (Janvier, 1933; Rayment, 1935; Michener and Lange, 1957), in Colletes they are more commonly arranged in series. In most of the other solitary bees except the megachilids, the cells are lined with a thin layer of wax-like or varnish-like waterproofing material. These secretions are salivary in the case of colletids, andrenids, and halictids, abdominal in some anthophorines (G. E. Bohart, in litt.). The cells of the Megachilidae are not constructed from the substrate but are made from foreign materials. Most Megachile utilize leaves or sections cut from leaves, or flower petals and sepals, but some use mud or pebbles with or without leaves. Trachusa uses leaf sections cemented together with resin or gum, Heteranthidium sand cemented with resin, Dianthidium and Chelostomoides pebbles cemented with resin, Serapista plant fibers attached to trees, Callanthidium and Anthidium plant down in cavities in the ground, plant stalks or wood. Callanthidium plugs its burrow with sand and resin, Anthidium with small stones. The habits of Osmia are quite varied, some using mud, others masticated leaf material, others the two combined, and still others resin.

The cells are provisioned with pollen and usually also with nectar. In the Andrenidae, Melittidae, and certain others the nectar added is sufficient to make the pollen dough-like and it is molded into a ball. In other cases it is stored quite dry (Lithurge) or with a coating of dry pollen (certain smaller Megachilini). The colletids and many anthophorines provide a rich mixture of nectar and the food store may be semiliquid or gruel-like. In Tetralonia malvae (Rossi), gruel-like provisions are covered with a thin layer of transparent honey (Malyshev, 1936). For most Anthophora about one half of the food is liquid. The larva utilizes this up to the final instar when it consumes the solid material (G. E. Bohart, in litt.). 
Lithurge fuscipennis (Lepeletier) oviposits in a pocket in the pollen during the process of securing the provisions (Malyshev, 1930), as do certain species of Osmia (G. E. Bohart, in litt.) but, in so far as known, other solitary bees lay their eggs after provisioning is complete. Depending upon the group, the position of the egg is usually quite characteristic. Usually it is placed on the provisions attached by one or both ends or floating if the texture of the material requires. However, Ceratina attaches the egg to the side wall of the cell so that it is partially covered by the pollen (Malyshev, 1936), certain Osmia insert the egg partially into the pollen, and the North American emphorines place the egg beneath the stores (Linsley, MacSwain, and Smith, 1956b). Colletes attaches the egg to the cell wall away from the food, as do the parasitic Anthophorinae (e.g. Melecta, Nomada).

Jacobs (1924) points out that females of most solitary bees possess integumentary scent glands. Originally functioning as a sex attractant, they apparently provide a distinctive nest odor in Mesotrichia (Skaife, 1952) and probably other bees.

Development and Overwintering. After oviposition the cell is sealed, often with a flat disk of mud, spirally ridged internally. When the larva hatches it feeds on the stored provisions, grows rapidly, passes through an uncertain number of instars, and usually requires a few weeks to complete development, but in Nomia melanderi Cockerell development from egg to full grown larva may require as little as eight days (G. E. Bohart, in litt.). Megachilids void feces very early in larval life (Michener, 1953b; van Lith, 1957) and during the last instar frequently weave them into the fabric of the cocoon. Other bees defecate on the cell walls but, at least in some cases, only after full larval growth. However, there are some exceptions (Linsley, MacSwain, and Smith, 1956a). This developmental sequence usually is followed by a diapause during which the bee is very resistant to alterations in the physical environment. Among bees with a single annual generation this diapause usually lasts for the major part of the year, and under conditions unfavorable to bee activity it may extend over two or more years. This is the overwintering stage for most solitary bees. It is followed in the spring by a brief period prior to pupation and emergence during which the larva is active but nonfeeding. Andrena and most Osmia, however, transform in the fall and overwinter in the natal cell as unemerged adults. Among species of Xylocopa and Ceratina larval diapause is apparently short, evanescent, or nonexistent, and development is direct, the mature adults emerging and overwintering gregariously in old burrows or hollow stems. [Friese (1901) records the overwintering of Xylocopa in abandoned burrows of Anthophora.] In general, solitary bees, other than megachilids, do not construct a cocoon (Macropis, Systropha, and emphorine Anthophorinae are among the exceptions). The Megachilidae spin mammillate cocoons which have considerable phylogenetic significance, and various subgroups in the family may be distinguished by the degree of development of the apical nipple. Among halictine bees, at least in cold climates, males emerge in the summer and fall, mate and then die, only the females overwintering. Even in southern California only females of most species may be found from January to May (Timberlake, in litt.). 
Sleep. Nesting females generally spend the night in their burrows and usually bar other individuals by means of a plug. Some males (e.g. many panurgines) curl up in the center of a flower [Banks (1908); Lieftinck (1957)], or, along with non-nesting females, may use emergence holes or deserted burrows (e.g. some Andrena) or may dig temporary burrows for night shelter (e.g. some Nomia and Anthophora). In Nomia several hundred males have been found in a single pocket (G. E. Bohart, in litt.), in Osmia they sometimes gather in cracks (Hirashima, 1957), and in Anthophora the burrows may be used gregariously by both sexes or even by host and parasitic bees (Linsley, 1943). Males of many solitary bees spend the night congregated in large number (Buttel-Reepen, 1915). Certain species of Eucera, Chelostoma, and Anthidium grasp a stem with the mandibles and rest with the body extended in the manner of sphecids (Friese, 1923). Both sexes of Coelioxys grasp the stem with the mandibles with the body upside down and the legs tucked in closely (G. E. Bohart, in litt.). Svastra, Melissodes, and Exomalopis grasp the stem with all six legs as well as the mandibles (Schwarz, 1901; Rau, 1916) and may be oriented with the head up as in M. bimaculata (Lepeletier) (Banks, 1908) or down as in S. obliqua (Say) and M. perplexa Cresson (Mathewson and Daly, 1955). According to Rayment (1935) the jaws of sleeping bees may clamp so tightly in such cases that large raindrops striking the body will decapitate the bees. Mixed aggregations of sexes and even species have been recorded as sleeping together by Banks (1908), Rau (1916), and Rayment (1935). The latter reports males and females of Anthophora saltera Cockerell, A. cinctofemorata Cockerell, and Asaropoda punctata Rayment together on the same stems. Rayment also records from Australia large nocturnal clusters (100 to 300 males) of various species in the genera Paracolletes, Heterocolletes, Stenotritus, and Nomia, on leaves and in bracken fronds. Similar aggregations of eucerine bees have been observed in Perú (E. S. Ross, in litt.) and of Nomia in Java (Lieftinck, 1957). Rayment found that the temperature is increased by this clustering, and Grassi (1942) considers gregarious sleeping a, possible stage in the evolution of social habits.

Matinal and crepuscular bees sleep in the day time. Thus, males of Xenoglossa and Peponapis spend the day in flowers of Cucurbita (Bradley, 1919); Linsley, MacSwain and Smith, 1956a).

\section{FOOD HABITS AND FLOWER RELATIONSHIPS}

All species of bees are dependent upon flowers for their basic food. As with most organisms, food habits have played an important role in their evolution and speciation. The choice of larval food, as is usually the ease with plant-feeding insects, is made by the adult. The larval food is pollen, usually mixed with some nectar, gathered from flowers by the female bee. However, bees may visit flowers for a variety of reasons, other than pollen collecting (Taniguchi, 1956). Flowers provide adult food (nectar and some pollen), the site of mating for many species, and a sleeping place for others. The collection of pollen by females invokes the most consistently specific response to flower species, although in some cases the mating search by males may be equally specific. 
The broad subject of the interrelations of flowers and insects has been primarily the concern of botanists (e.g. Kölreuter, 1761; Sprengel, 1793 ; Delpino, 1867 ; Hildebrand, 1867 ; Müller, 1873 ; Kerner, 1876 ; Plateau, 1877, 1895 ; Knuth, 1898-99 ; Kirschner, 1911 ; Lovell, 1918; Knoll, 1921-1926 ; Clements and Long, 1923; Robertson, 1928 ; Graenicher, 1935 ; Grant, 1950 ; et al.). Some of these students have made substantial contributions to entomology and to bee ecology, but by and large the majority have approached the problem from the standpoint of floral ecology. Thus, Sprengel (1793) is credited with being the first to attach significance to flower color, scent, and form from the viewpoint of their relation to insect pollination. Sulsequently Darwin (1859) gave impetus to the investigation of this aspect of the problem by emphasizing the importance of cross pollination. Müller attempted to apply the Darwinian theory of evolution to flowers and the insects which visit them in a series of important papers which culminated in his classical work on the fertilization of flowers (1873), the basic reference work for students of pollination. Grant (1949) has provided an informative and up-to-date discussion of the role of insects, especially bees, in relation to pollination systems, evolution, and speciation among angiosperms.

Near the turn of the century, entomologists began to contribute substantially to the knowledge of the interrelationships of bees and flowers, especially in parts of North America and Europe. However, important papers also appeared on the flower relationships of South American species, especially of Argentina (Jensen-Haarup, 1907, 1908; Jörgensen, 1909, 1912a, $1912 b$ ) ; Brazil (Ducke, 1901, 1902 ; Schrottky, 1901; von Ihering, 1905), Amaral (1953), and Paraguay (Schrottky, 1908, 1909 ; Bertoni, 1911). Recent contributions to the subject have been largely a by-product of thorough taxonomic treatments of various groups of bees (e.g. Timberlake, 1954, 1956) or life history studies (e.g. Michener and Rettenmeyer, 1956 ; Linsley and MacSwain, 1958 $a, b$ ), and considerable light has been shed on certain aspects of the problem, especially flower constancy, by research workers in fields of agriculture such as orchard management (e.g. Brittain, 1933; Phillips, 1933 ; Butler, 1945), legume seed production (e.g. Linsley and MacSwain, 1947; Bohart, 1957; Popov, 1951b, 1952c, 1956), and contamination of vegetable seed crops (e.g. Bateman (1947); Crane and Mather (1943)).

Flower Constancy. Constancy in the collection of pollen is a characteristic of bees in general. Two types are involved. The first is characteristic of individual bees which, on one or several successive trips may gather pure (or nearly pure) loads of pollen from one kind of plant, although the species as a whole may be polylectic and not sharply limited in the kind and number of pollen sources utilized. This kind of constancy has long been known to floral biologists, students of insect behavior, apiculturists, and research workers in certain production aspects of agriculture. It is characteristic of social bees (e.g. Apis, Bombus, Melipona), semisocial bees (e.g. Halictus), and many solitary bees (e.g. some Anthophora, Andrena, Megachile). Plateau (1902) has described errors, largely by Apis and Bombus, in visiting flowers, and Bateman (1951) has discussed discrimination between species and varieties of Brassica. However, samples from bees with mixed loads may be 95 to 
99 per cent pure (Grant, 1950), and may result from accidental contamination while visiting other flowers for nectar.

The second kind of constancy was partially recognized by Loew (1884) and was more clearly defined by Robertson (1925). ${ }^{7}$ It is adaptive in nature and is characteristic of species, genera, and even higher groups of bees. This form of flower constancy is oligolecty, and is usually reflected in physiological and morphological adaptations which sharply limit the number and kind of pollen sources normally utilized by bees with this inherited characteristic. However, the term is relative and should be used accordingly (Popov, 1956; Linsley and MacSwain, 1958a, $b$ ).

The general subject of flower constancy has been comprehensively reviewed by Grant (1950) and certain phases have been discussed recently by Popov $(1952 a, 1952 b, 1956)$ and Michener $(1953 a, 1954)$. The latter author comments on difficulties associated with the definition of the term oligolecty. The definition here adopted is that of Linsley and MacSwain (1958a). These authors define as oligolectic those species in which the individual members, throughout the range of the population, and in the presence of other pollen sources, consistently and regularly collect pollen from a single plant species or a group of related plant species, turning to other sources, if at all, only in the face of a local absence of the pollen. Monolecty, as defined by Robertson (1925), usually results from a monotypic plant genus or from a single species of a plant genus occurring in the region occupied by the bee; it thus does not appear to differ from oligolecty.

Oligolectic species usually exhibit physiological adaptations to the host flower, such as short seasons more or less synchronized with the blooming period of the plant; frequently, daily flight periods coinciding with special diurnal periods of pollen availability; sometimes psychological adaptations to certain flower colors ; in some cases cryptic coloration matching the flower; and often morphological adaptations for the extraction or transport of the pollen or to facilitate the simultaneous extraction of nectar from the pollen plant. However, Popov (1956) states that certain "relict" genera of bees (e.g. Xylocopa) are almost completely unadapted to pollination of modern flowering plants, but Nishida (1958) has demonstrated that carpenter bees are certainly adapted to pollination of flowers of the passion vine. Although Werckmeister (1951) records Xylocopa violacea Linnaeus as an assiduous worker of bearded iris (Iris germanica), interfering with plant breeding, and the chief pollinator of the little iris (Hermodactylus tubersosus) in the Mediterranean region, he also regards it as the primary factor in seed set of Wistaria chinensis and everlasting pea (Lathyrus odoratus).

Oligolectic Bees. Malyshev (1936) considers the great majority of solitary bees to be more oligolectic or monolectic than polylectic. He cites as examples

${ }^{7}$ Loew (1884) observed differences in the flower visiting habits of bees with tongues of about equal length (thus presumably with the same nectar sources available) and designated monotropic, oligotropic, and polytropic types, depending upon whether they visited a single species of plant, related species of plants, or unrelated plants, respectively. At first, Robertson (1899) adopted Loew's terminology but limited the application of the terms to flower visits for pollen. Later he proposed the parallel terms monolectic, oligolectic, and polylectic for use in reference to pollen visits of bees, restoring Loew's terminology to its original meaning (Robertson, 1925). 
TABLE 3

OLIGOLECTIC BEES OF CARLINVILLE, ILLINOIS (After Robertson, 1926)

\begin{tabular}{|c|c|}
\hline Oligolege & Pollen source \\
\hline Colletes aestivalis Patton. & Heuchera hispida \\
\hline albescens Cresson...... & Petalostemum purpureum \\
\hline robertsonii Dalla Torre.. & Petalostemum purpureum. \\
\hline brevicornis Robertson... & Specularia perfoliata \\
\hline latitarsis Robertson... & Physalis \\
\hline willistonii Robertson. & Physalis \\
\hline 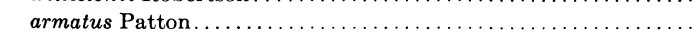 & Astereae \\
\hline americanus Cresson............................... & Astereae, Heliantheae \\
\hline 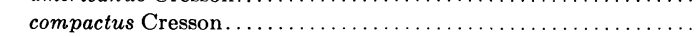 & Astereae, Heliantheae, Helenieae \\
\hline 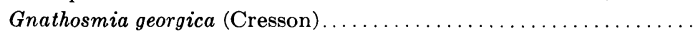 & Astereae, Heliantheae, Cinchorieae \\
\hline Ashmeadiella bucconis (Say)..... & Astereae, Heliantheae \\
\hline 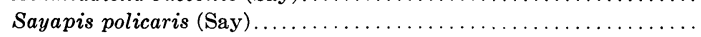 & Heliantheae \\
\hline pugnata (Say)........ & Heliantheae, Cynarieae \\
\hline sayi (Cresson).. & Heliantheae, Cynarieae, Eupatorieae \\
\hline Megachile sexdentata Robertson. & Heliantheae, Astereae \\
\hline strophostylis Robertson....... & Strophostyles helvola \\
\hline generosa Cresson............. & Leguminosae \\
\hline Sarogaster georgicus (Cresson)... & Papilionaceae \\
\hline Anthidium psoraleae Robertson. & Papilionaceae \\
\hline Oligotropus campanulae Robertson......... & Campanula americana \\
\hline Trachandrena spiraeana Robertson .................. & Aruncus sylvester \\
\hline mariae Robertson.................... & Salix \\
\hline Andrena erythrogastra (Ashmead) . . . . . . . . . . . . . & Salix \\
\hline illinoensis Robertson $\ldots \ldots \ldots \ldots \ldots \ldots \ldots \ldots \ldots \ldots$ & Salix \\
\hline macoupinensis Robertson. & Salix \\
\hline nigrae Robertson ................................ & Salix \\
\hline salicacea Robertson & Salix \\
\hline 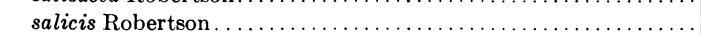 & Salix \\
\hline salictaria Robertson .............................. & Salix \\
\hline arabis Robertson ..................................... & Cruciferae \\
\hline nothoscordi Robertson........................... & Nothoscordum striatum \\
\hline nubecula Smith.............. & Astereae \\
\hline Pterandrena asteris Robertson... & Astereae \\
\hline solidaginis Robertson........ & Astereae \\
\hline helianthi Robertson................. & Astereae, Heliantheae \\
\hline aliciae Robertson ........................ & Heliantheae \\
\hline pulchella Robertson................... & Heliantheae \\
\hline rudbeckiae Robertson. ............................. & Heliantheae \\
\hline krigiana Robertson................... & Krigia amplexicaulis \\
\hline Ptilandrena erigeniae Robertson. & Claytonia virginica \\
\hline g. maculati Robertson.......... & Geranium maculatum \\
\hline polemonii Robertson........... & Polemonium reptans \\
\hline 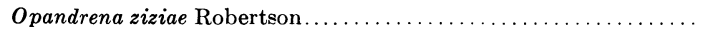 & Umbelliferae, zizioid \\
\hline 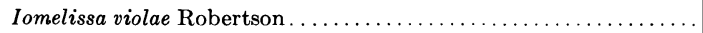 & Viola \\
\hline 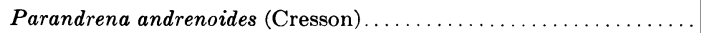 & Salix \\
\hline Chloralictus nymphaearum (Robertson).............. & Nymphaeaceae \\
\hline Macropis steironematis Robertson . . ........................ & Steironema \\
\hline 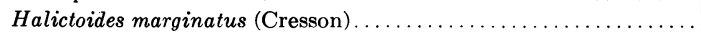 & Helianthus \\
\hline 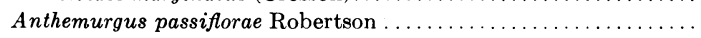 & Passiflora lutea \\
\hline 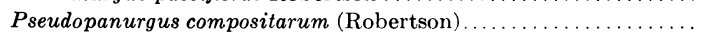 & Astereae \\
\hline 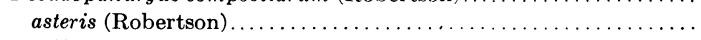 & Astereae, Heliantheae \\
\hline solidaginis (Robertson).... & Astereae, Heliantheae \\
\hline alibitarsis (Cresson)........ & Heliantheae \\
\hline labrosiformis (Robertson). & Heliantheae \\
\hline labrosus (Robertson)...... & Heliantheae \\
\hline rudbeckiae (Robertson).... & Heliantheae \\
\hline rugosus (Robertson)... & Heliantheae \\
\hline Perdita ootomaculata (Say)........ & Astereae, Heliantheae \\
\hline
\end{tabular}


TABLE 3-Continued

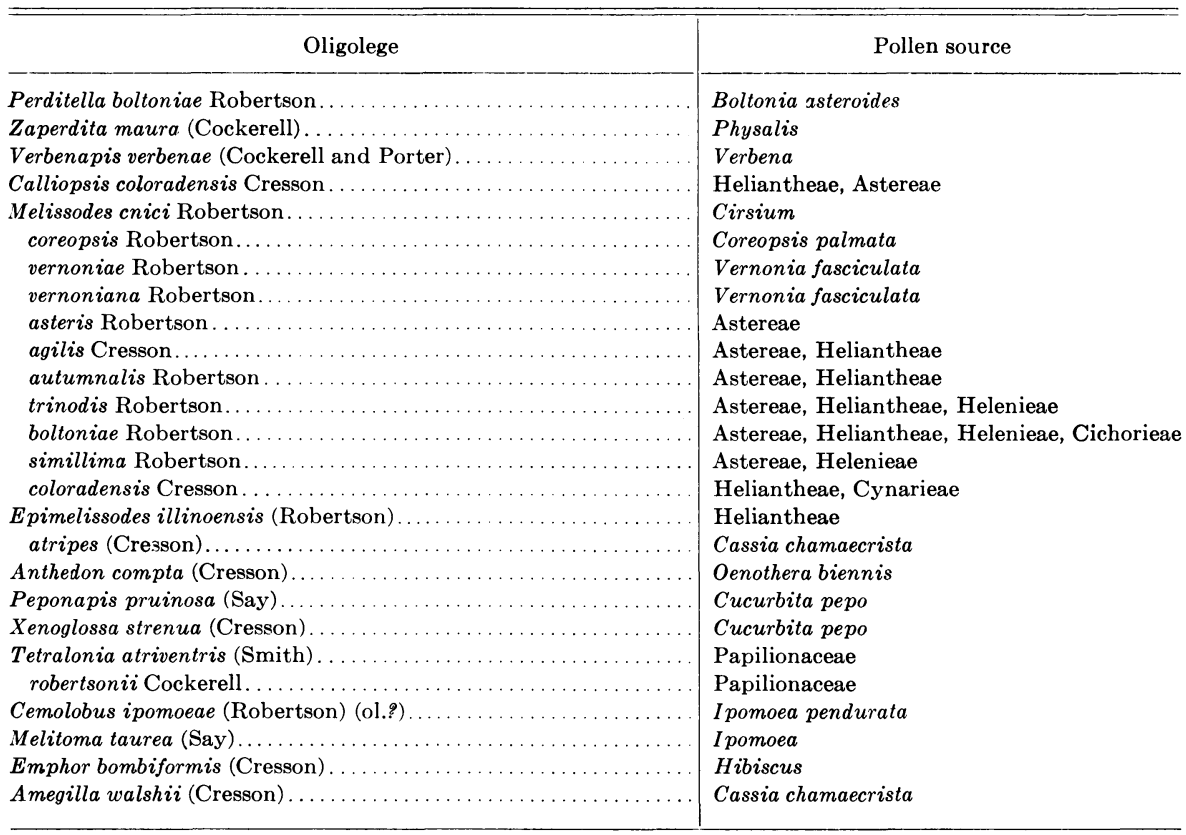

of monolectic species Andrena florea Fabricius which collects pollen only from Bryonia alba, and Macropis labiata (Fabricius) which is restricted to Lysimachia vulgaris, and as oligoleges, Tetralonia malvae Rossi which gathers pollen from Lavatoria thuringiana or Althea officinalis, Meliturga clavicornis (Latreille) which collects from Melilotus officinalis or Medicago sativa, and Melitta leporina (Panzer) which takes pollen from Medicago falcata, Melilotus officinalis or Trifolium montanum. Other species are listed for Middle Asia by Popov (1956). The most complete account of the oligolectic bees of a region of North America has been provided by Robertson (1926). His list (table 3) for Carlinville, Illinois, is of interest as an example of what might be expected in a nonarid, temperate locality. This list exhibits oligolecty at the group level (Sayapis, Pterandrena, Pseudopanurgus, Melissodes) as well as at the species level.

Some oligolecty is evident at the family level, e.g., generally speaking anthophorine and megachilid bees choose a different series of flowers from the colletid and andrenid bees. At the generic level it is well illustrated by the species of Macropis (Malyshev, 1936; Michener, 1951b; Popov, 1956), Chelostoma (Michener, 1938) and Proteriades (Timberlake and Michener, 1950 ; Hurd and Michener, 1955). The species of the first group gather pollen only from flowers of Lysimachia and Steironema (Primulaceae), the second from Hydrophyllaceae, principally Phacelia and Eriodictyon, and the third group only from Cryptantha (Boraginaceae). Until recently, twenty-two species of Proteriades were known; all of these occur in California and 


\section{TABLE 4}

OLIGOLECTY IN SOME SUBGENERA OF PERDITA

(Compiled from Timbərlake, 1954, 1956)

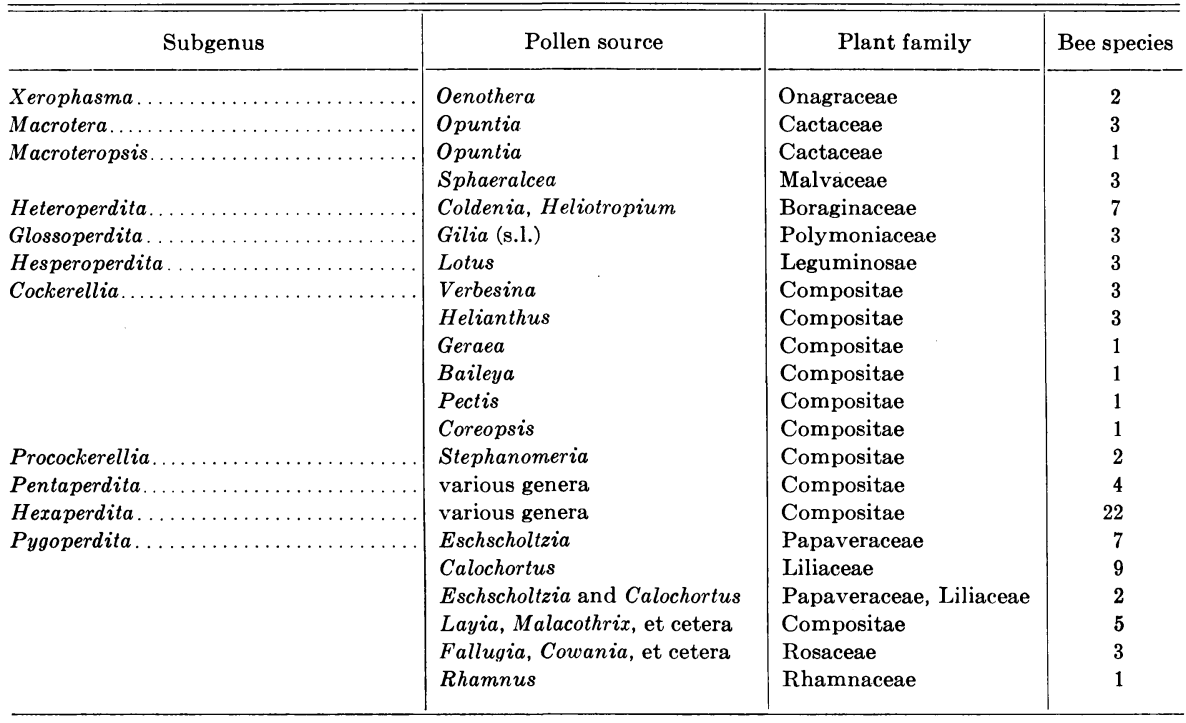

TABLE 5

OLIGOLECTY IN CALIFORNICA GROUP OF PERDITA (PYGOPERDITA) (Compiled from Timberlake, 1956)

\begin{tabular}{|c|c|c|}
\hline Species & Pollen source & Region \\
\hline 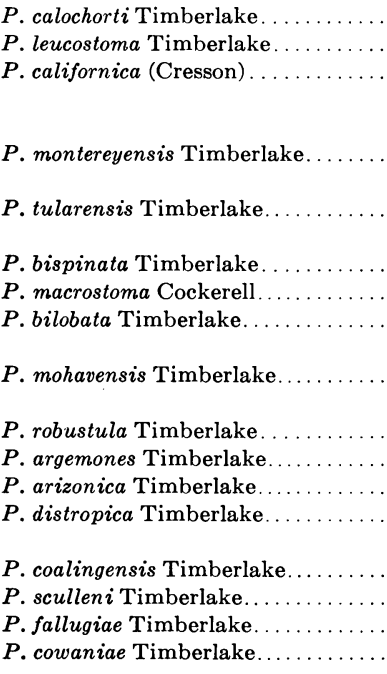 & $\begin{array}{l}\text { Calochortus nutallii } \\
\text { Calochortus leichtlinii } \\
\text { Calochortus splendens } \\
\text { Calochortus kennedyi } \\
\text { Calochortus concolor } \\
\text { Calochortus splendens } \\
\text { Eschscholtzia californica } \\
\text { Calochortus venustus } \\
\text { Calochortus luteus } \\
\text { Calochortus kennedyi } \\
\text { Calochortus sp. } \\
\text { Calochortus aureus } \\
\text { Calochortus kennedyi } \\
\text { Eschscholtzia darwiniensis } \\
\text { Eschscholtzia glyptosperma } \\
\text { Eschscholtzia darwiniensis } \\
\text { Argemone sp. } \\
\text { Calochortus sp. } \\
\text { Calochortus splendens } \\
\text { Eschscholtzia californica } \\
\text { Eschscholtzia californica } \\
\text { Callochortus mutallii } \\
\text { Fallugia paradoxa } \\
\text { Cowania stansburiana }\end{array}$ & $\begin{array}{l}\text { San Bernardino Co., Calif. } \\
\text { Inyo Co., Calif. } \\
\text { Coastal central and Southern Calif. } \\
\text { Monterey Co., Calif. } \\
\text { Southern Sierra Nevada Mts., Calif. } \\
\text { Mojave Desert, San Bernardino Co., Calif. } \\
\text { Los Angeles Co., Calif. } \\
\text { Inyo and San Bernardino Co., Calif. } \\
\text { Mojave and Colorado Deserts, Calif. } \\
\text { Colorado Desert, Calif. } \\
\text { Arizona } \\
\text { Coconino Co., Ariz. } \\
\text { Coastal central Calif. } \\
\text { Fresno Co., Calif. } \\
\text { Utah } \\
\text { Charleston Mts., Nevada } \\
\text { Panamint Mts., Calif. }\end{array}$ \\
\hline
\end{tabular}


half of them have been taken at Riverside on Cryptantha intermedia. As in the case of most generic oligolecty, Proteriades is morphologically adapted for the removal of pollen from this group of plants. However, Michener and Sokal (1957) have revised the concept of this genus and included certain elements not associated with Cryptantha.

The genus Anthocopa (Michener, 1943; Hurd and Michener, 1955) exhibits oligolecty at the level of the subgenus and species group. Thus Atoposmia is made up of species which take pollen from Penstemon (Scrophulariaceae), Hexosmia from Phacelia and Nemophila (Hydrophyllaceae), and Eremosmia breaks up into three groups, one of which utilizes pollen only from Compositae, the other two largely from Leguminosae.

The genus Perdita is one of the most striking groups of oligolectic bees (Cockerell, 1896). Table 4 summarizes oligolecty in most of the subgenera which have been recently revised by Timberlake $(1954,1956)$. Of particular interest is Pygoperdita which has its center of distribution in California (27 species), with five species known from Nevada, three each in Oregon and Utah, two each in Washington and Arizona, and one each in Colorado and Baja California. Timberlake (1956) recognized two species groups. The Interrupta group contains at least four species which obtain pollen from Eschscholtzia, one each from Rhamnus and Adenostoma, and five closely related species which collect from Compositae. The Californica group (table 5) included at least three species which gather pollen from Eschscholtzia, nine species from Calochortus, and at least two species which regularly take pollen from both.

Oligolecty and Entomophilous Flowers. In those regions where oligolecty is pronounced, the pollen flowers are usually scattered taxonomically through the local families of plants with entomophilous flowers. However, both Graenicher and Robertson have pointed out the special significance of the Compositae. In fact Graenicher (1935) considers it not only the largest but possibly the most important family with entomophilous flowers. Of the 921 flower species growing in Milwaukee Co., Wisconsin, he established 628 as entomophilous and 152 of these (24.2 per cent) were Compositae. The close grouping of the tubular florets in an infloresence is especially attractive to bees, and he found that of 41 local oligoleges, 21 were associated with Compositae, especially fall-blooming species. He notes further that of the 54 species of Wisconsin oligoleges known to him, 20 were eastern in distribution and 34 exclusively or primarily western. Of these last, 19 are specific to Compositae which are largely characteristic of the western prairie flora.

Oligolecty in the Tropics. Michener (1954) states that for some reason, possibly connected with the relatively small seasonal variation in climate, there are few oligolectic bees in the American tropics as compared with any comparable faunal list from the temperate regions. His Panamá list contains several bees which belong to oligolectic genera (Ancyloscelis and Melitoma which obtain pollen only from Ipomoea, Peponapis only from Cucurbita). He suggests that these oligolectic bees arose in more arid areas, where competition for pollen is more intense, and later spread into the moist tropics.

The pollinating species usually cited for agricultural crops in tropical 
areas are polylectic forms. Thus, Burkhill (1909) considers various species of Xylocopa to be the most important of the flower-visiting insects of tropical India (plains region) and largely responsible for the pollination of Sunn hemp and possibly Indian pulses. $X$. latipes Fabricius and $X$. aestuans (Linnaeus) visited 30 and 35 jute flowers per minute respectively. However, Maxwell-Lefroy (1909) cites Lithurge atratus Smith, presumably an oligolege of Malvaceae, as a persistent visitor of cotton plants in the same general region.

\section{ADAPTATIONS ASSOCIATED WITH OLIGOLECTY}

Ability to Locate the Appropriate Pollen Source. It has long been maintained that the bright colors of flowers were evolved for the visual attraction of pollinators (Lubbock, 1882; Müller, 1873) and that flower colors in the medium and ultraviolet ranges were particularly attractive to bees. Colors in the visual range of the bee (von Frisch, 1915; Kühn and Pohl, 1921; Kühn $1927)^{8}$ no doubt serve a useful purpose in attracting the casual nectar seeker and together with the form and pattern of the flower, location on the plant, and certain other features may ease the task of the pollen collector and assist in pollen constancy (Lovell, 1909-1910, 1918). However, the only prior experience which the newly emerging solitary oligolege has had with its appropriate pollen source is the pollen and nectar which were stored by its parent. Presumably it must rely upon its olfactory and/or gustatory senses to guide it to the proper flower. The essential role of odor for insects which visit flowers was first emphasized by Plateau (1897, 1907) and the sensitivity of the olfactory organs of bees has been noted by various workers (McIndoo, 1914; von Frisch, 1919). Rayment (1935) reports that Australian tea-trees (Leptospermum spp.) are attractive (presumably by odor) to Euryglossa fasciatella Cockerell before the blossoms open, and G. E. Bohart (in litt.) has made similar observations of Andrena males and some females about Salix. Bees also recognize form in flowers (von Frisch, 1919; Hertz, 1929; Autrum, 1948, 1949). In addition, many flowers have maculae indicantes, the so-called "nectar guides" or "honey marks" (Sprengel, 1793) which guide the bee to the nectaries, and which may have a different scent from the rest of the flower

Michener (1953b) has shown that Megachile brevis Say, although taking pollen from plants as widely separated as the Leguminosae and Compositae, exhibits a preference for blue or purple flowers, and its principal sources are of these colors. Less important sources are white or greenish, and one minor source, yellow. Yet in the area where the study was made there are large numbers of yellow Compositae.

Leclercq (1945) has reported on the solitary bees which visited green hellebore (Helleborus viridis Linnaeus) in his garden. The petals and sepals of this flower are green, like the foliage, and its other features appear to mini-

\footnotetext{
${ }^{8}$ The color sense of bees is summarized by Grant (1950) and involves the perception of four main groups: (a) a yellow group which includes vermilion, orange, yellow, and yellow-green; $(b)$; blue-green; $(c)$ a blue group which includes blue, purple, and violet; and $(d)$ ultraviolet. Bees are color blind for pure red. They distinguish different degrees of brightness as white, gray, and black but do not distinguish different shades within one color group.
} 
mize visual contrast. It has no detectable odor, yet it was regularly visited by Andrena albicans (Müller), Osmia cornuta (Latreille), O. rufa (Linnaeus), Halictus calceatus (Scopoli), and Bombus hypnorum (Linnaeus), even in the presence of highly perfumed and brightly colored violets (Viola tricolor Linnaeus). At the same time it was consistently ignored by foraging honey bee workers and by both sexes of Andrena fulva (Schrank). Leclereq suggests that hellebore provides a particular scent to which bees are able to respond but which is outside the range of sensitivity of man. However, von Frisch $(1919,1921)$ has pointed out that the reactions of the olfactory organs of man and honey bees are much the same and that flowers which are odorless to us are also odorless to bees, although the latter can distinguish the scent of each species that has one. In the case of Helleborus, it is likely that bees recognize the ultraviolet color. Lotmar (1933) points out that red poppies (Papaver) are recognized by reflected ultraviolet light, and Hertz (1939) emphasizes that flowers that appear white to us are colored for bees and may look blue-green to them.

Leppik (1957) has discussed some aspects of the problem of evolutionary relationship between entomophilous plants and anthophilous insects. He concludes that the evolution of entomophilous plants has been controlled by insects (primarily bees) through the sensory behavior of the pollinators, that this selection tends to keep the evolution of flowering plants in a predetermined sequence, that various stages in the sensory development of pollinating insects are reflected in corresponding levels in the evolution of flower types, and develops a presumptive sensory mechanism which governs the food searching instincts of anthophilous insects and regulates their selective activity among flowers. Unfortunately, his argument is weakened by the fact that the literature and examples he cites pertain to the social bees (honey bees, bumble bees, stingless bees) and consideration is not given to the role of the solitary bees, numerically superior through time and space in both species and individuals. Further, the social bees are extremely polylectic, a large proportion of the solitary bees are oligolectic. Although visual and olfactory perceptions are known to be highly developed in social bees, little is known of their level in solitary bees. Also, Leppik takes no cognizance of the long series of morphological, physiological, and ethological adaptations of various oligolectic solitary bees to the plants which serve as their sources of pollen. Finally, of the bees to which he refers, only Bombus occurs naturally in the vast temperate flora of the Northern Hemisphere, and the size and weight of individual workers of most species in this genus limit their selective value to certain kinds of plants. If Leppik's thesis is correct, and I am not convinced that it is, the semisocial halictines may have assumed in the Northern Hemisphere, the selective role that he attributes to "bees." However, little is known regarding the level of sensory perception of this group or, for that matter, of polylectic solitary bees.

Seasonal Synchronization with Pollen Source. Synchronization of adults of certain bees with the blooming period of their host plant has been noted by many writers (e.g. Loew, 1884; Robertson, 1889, et seq.; Graenicher, 1909), mostly based upon observation and collections made at the flowers. However, studies of actual emergence of the bees from the ground in relation 
to the appearance of the first bloom sufficiently abundant to be useful, has revealed that the degree of concurrence of the two events may vary considerably from season to season, not only with annuals and small perennials but also with flowering shrubs (Malyshev, 1936; Ulrich, 1933; Michener and Rettenmeyer, 1956 ; Linsley and MacSwain, 1957). However, most data thus far reported indicate reasonably close synchronization between oligolectic bees and their pollen sources. Possibly because of the limitations inherent in a single pollen source, the seasonal period of flight is usually shorter for oligoleges. Graenicher (1909) reports the average flight period for Wisconsin oligoleges as 44 days, for polyleges, 63 days, the latter flying 43 per cent longer. Robertson (1922) considered 85 per cent of the local Illinois Panurginae to be oligolectic, with flight periods averaging 53 days. Two species which were polylectic averaged 143 days (possibly more than one generation was involved). However, under desert and high montane conditions more extreme restriction may occur.

Since the preëmergence and prebloom environments of the bee and the flower are quite different, the physical and biological basis of synchronous timing is of considerable interest. Early spring bees (e.g. Andrena) usually overwinter as adults in the pupal cells in which they transformed. Most bees, however, overwinter as larvae and must pupate, transform, and harden before emergence. In either case these events take place from less than an inch to several feet below the surface, depending upon the species, and it is not clear how the bee and the flower can be attuned to the same stimuli. That moisture may be the key, at least in desert forms which overwinter as larvae, is suggested by Hurd (1957). He notes that Geraea canescens, a spring annual of the Mojave and Colorado deserts, bloomed in October, 1951, as a result of unseasonal rains of more than an inch. Its oligolege Hesperapis fulvipes Crawford, normally a spring bee, appeared at the same time. Since Geraea requires about an inch of rainfall for germination and since this amount of rain moistens the desert soil to a depth of from 18 to 24 in. (sufficient to reach the cells of the bee), a timing mechanism is available if the maturation process of the bee is initiated by moisture. In boreal areas, emergence of early spring forms which overwinter as adults appears to be associated with rising temperatures (Ulrich, 1933). However, this is also true in the case of Nomia melanderi Cockerell, and emergence of this species may be accelerated by placing polyethylene sheets over the ground and delayed by mulching the soil (G. E. Bohart, in litt.).

The short seasons of oligolectic bees have a tendency to provide concurrent variations in seasonal abundance of bee species. Graenicher (1909) recognizes two such peaks in Wisconsin; Stevens (1948), three peaks in North Dakota.

Seasonal Variation in Activity in the Tropics. In a tropical climate variations in the activity of animal life are at a minimum, but the variation is nonetheless considerable. Thus, in most parts of Panamá (Michener, 1954) there is a dry season beginning in mid-December and continuing to April or May. On the Pacific coast in the Canal Zone area, in spite of an annual rainfall in the vicinity of 60 in., the dry season is virtually without rain. In the early part of the dry season, while conditions are moist 
but the days mostly clear and sunny, numerous herbaceous annual and perennial plants come up and bloom. It is at this season that bees known to have short seasons of flight can be found, and some of these appear to be intrusions from the north temperate regions (e.g. Andrena vidalesi Cockerell, Calliopsis hondurasica Cockerell).

Diurnal Synchronization with Pollen Source. Perhaps the most striking cases of synchronization with the pollen source are to be found among the crepuscular and matinal bees which gather their pollen after sunset or before sunrise. Many of these take their pollen from evening primroses (Oenothera and related Onagraceae). The best known of the semisocial crepuscular forms belong to Sphecodogastra, a subgenus of Lasioglossum (Halictidae), which has enlarged ocelli (almost universally associated with nocturnal habits in the bees) and a scopa modified for extracting the strands of pollen characteristic of onagraceous flowers. Four species are known, all of which collect pollen in the early hours of the night from evening primroses (Graenicher, 1911; Stevens, 1920). The group is closely related to the subgenus Evylaeus, which contains several species which gather pollen from diurnal Onagraceae and thus have the scopa similarly modified but have normal ocelli (Hurd, in litt.). A related neotropical halictine genus, Megalopta, also has large ocelli and Ducke (1902) records the capture of pollenladen females at light at night in South America. Rau (1933) found a specimen of M. genalis Mead-Waldo in the laboratory on Barro Colorado Island, Canal Zone, at 6 a.m. Schwarz (1934) records 15 females and one male of this species taken at light at the same locality. However, pollen from four different plant species was being carried by different females indicating that this species, at least, is polylectic. The genus Perdita (subgenus Xerophasma) contains two large, pallid, nocturnal species with enlarged ocelli which collect pollen from Oenothera and are sometimes attracted to light (Cockerell, 1923; Timberlake, 1954).

Species of the eucerine genus Xenoglossa gather pollen from Cucurbita flowers before sunrise (Linsley, MacSwain, and Smith, 1956a), and the related genus Peponapis from sunrise until the flowers wilt or the pollen is exhausted. The andrenine subgenus Onagrandrena (see below) comprises bees which take pollen from Oenothera at dawn (Linsley, MacSwain, and Smith, 1955 ; Linsley and MacSwain, 1956). Caupolicana yarrowi (Cresson) another matinal species, was captured by Cockerell and Porter (1899) at flowers of Datura between 5:15 and 6:15 a.m. and Graenicher (1930) took a female during the same time of day at flowers of Antigonon. Schrottky (1907) made observations on two related South American species and concluded that on warm nights the bees are flying all night long. Ptiloglossa also contains matinal species and these have been observed in Mexico (Michener, in litt.) as well as in South America. Lasioglossum lustrans (Cockerell), an oligolectic halictine, is a matinal species which takes pollen only from Pyropappus carolinianus, the flowers of which close in the morning soon after the sun strikes them [Michener, 1947a]. The male of this species is considered by Michener to be as rigidly restricted in its flower visits as the female.

The Xylocopine subgenus Nyctomelitta comprises a number of nocturnal species with enlarged ocelli which inhabit the Indomalayan region. Of $X$. 
(N.) rufescens Smith (=X. (N.) tranquebarica, Fabricius), Bingham (1897) states that on fine moonlight nights its buzzing can often be heard all night long. These species are, however, probably not oligolectic. E. S. Ross and H. B. Leech (in litt.) report finding the New World Xylocopa rufina Maidl visiting flowers in the dim light of dusk in the undergrowth of a pine forest on the south slope of Mt. Colima, Mexico, in December, 1948. Williams (1927), on the other hand, heard the introduced Hawaiian species of Xylocopa buzzing loudly among blossoms before sunrise, suggesting that the members of this genus are able to adjust broadly to local conditions of pollen availability. This appears to be true also of certain oligolectic forms. Perdita species of the wootonae group collect pollen from Mentzelia near sundown in Arizona and New Mexico in the fall. However, Timberlake (in litt.) found them active in the middle of the afternoon at Blythe, California, in April, apparently because the flowers open earlier at that time of year. Further, some bees appear to utilize the early hours of both morning and evening. MacSwain (1957) has recorded Martinapis luteicornis Cockerell taking pollen from Cercidium between 6:00 and 8:00 a.m. on the Colorado Desert, California, in April, and visiting Dalea between 4:00 and 6:00 p.m. in October.

Linsley and MacSwain (1958c) have called attention to the fact that the loud buzzing of matinal and crepuscular bees is only produced after sunset and before sunrise, suggesting a sonar-like device. These bees are commonly black or dark colored, permitting maximum heat absorption, a phenomenon that may explain the black desert bees of Peru (Cockerell, 1926).

Morphological Adaptations. Structural modifications associated with oligolecty are relatively numerous. Generally they involve adaptations which assist in the extraction and transportation of pollen or nectar or both. Such adaptations are frequently associated with group oligolecty. Thus, the species of Verbenapis have curled bristles on the front tarsi and are oligoleges of Verbena. The anthers of this flower are included in a slender tube with a circle of hairs above, which limits most bees to the extraction of pollen which adheres to the proboscis. However, Verbenapis thrusts both front legs into the corolla tube and extracts the pollen by means of the bristles on the front tarsi. On the other hand, the pollen of Oenothera (evening primroses) and other Onagraceae is difficult to collect because it is connected by threads. Oligoleges of these plants almost always have scopae composed of long simple bristles. This is true of such widely separated groups as Anthedonia (Robertson, 1914), Diandrena (Cockerell, 1937), Onagrandrena (Linsley and MacSwain, 1956c), Diadasia (Linsley and MacSwain, 1958a), Anthophora, and others, and seems to be an obvious specialization. Oligoleges of Claytonia, Hibiscus, Geranium, the Cactaceae and various other plant groups have loosely plumose scopae adapted to hold large pollen grains, those dependent upon the fine pollen grains of the Compositae have densely plumose scopae (Robertson, 1902).

Most members of such groups also exhibit physiological adaptations to their pollen plants. However, in Proteriades, morphological adaptations appear to restrict the pollen source regardless of other considerations. In all of the known species the galeae and labial palpi are provided with stiff curled hairs which are utilized to extract pollen from the stamens of Cryptantha 
which are deeply hidden in the flower, but there is no evidence to suggest that the different species of Proteriades are restricted to different species of Cryptantha (Hurd and Michener, 1955). In fact the indications are that a species of Proteriades will utilize whatever Cryptantha species are available in the neighborhood. Hurd and Michener also state that there is no evident relationship between speciation in Cryptantha and that in Proteriades, and the distribution of the plant is far wider than that of the bee. Hurd and Michener (1955) point out further that in the vicinity of Riverside, where ten species of Proteriades are competing with one another on $C$. intermedia visiting the same flowers at the same season in the same place, the flight period of the bees does not even coincide with the main bloom of the Cryptantha plants.

Adaptations for the extraction of nectar from the pollen plant usually involve the length of the tongue (Taniguchi, 1954). They are most conspicuous in groups which collect pollen from plants with a deep corolla, and numerous examples are found among the higher bees. Included are such longtongued anthophorines as Ptilothrix, Melitoma, and Cemolobus which take pollen from Ipomoea, the dufourine subgenus Mimulapis which utilizes Mimulus, the osmiine subgenus Atoposmia which visits Pentstemon, the andrenine subgenus Iomelissa which is restricted to Viola, and a great many others. Chelostoma cockerelli Michener, which takes pollen from Eriodictyon also has elongated mouthparts, but the species crawls into the flower and does not use them (Hurd and Michener, 1955).

Origin and Significance of Oligolecty. Lovell (1913) has said that the oligotropic habit is not beneficial to plants but concerns bees alone. However, it appears quite obvious that bees which as individuals or as a species collect pollen from only a few species of plants are likely to be more efficient pollinators than those which utilize many. From the standpoint of the bee, oligolecty probably enables it to avoid or reduce competition. Robertson (1914) believed that the bee fauna is all the flora will support, that there is constant competition between bees, and that natural selection favors those which are least competitive in the food habits (i.e. oligolectic). Lovell maintained that no satisfactory evidence has been produced to show that oligotropism is an effort by bees to avoid competition. He believed that if there were a scarcity of pollen sufficient to promise severe competition it would be a disadvantage to restrict visits to one kind of plant. However, since oligotropism clearly restricts competition between species, then, from the standpoint of a single species, in times of pollen shortage competition would be between members of each species, not with other species. By this means each species would be assured a minimum of food for its own survival (by means of a few successful individuals), whereas, if all species in time of shortage were competing for the pollen of all flowers, the less able would be exterminated. Oligolecty reduces competition by distributing the bees in space (on different kinds of flowers) and in time (in different parts of the year in accordance with the period of inflorescence of the flower or at different periods during the blooming period of the plant species). Thus oligolecty may be viewed as a mechanism for the preservation of a great many species which might otherwise fail to survive and may account for the large number of species existing in highly oligotropic 
genera. In any one area, genera containing a high percentage of oligotropes possess many more species than those with a few oligotropes.

Michener $(1953 a, 1954)$ has pointed out that oligolecty is a form of host specificity. He comments that, in spite of the fact that polylectic species would appear to be at an advantage because they would be able to make use of more sources of food, their distributions would not be limited by those of a few hosts, and environmental changes which might eliminate the hosts and thus exterminate the oligolege might leave a polylectic species unaffected. Oligolectic species or groups of bees have arisen repeatedly from polylectic ancestors. From this it is obvious that specific adaptations must be advantageous as long as the proper environment is present. Such adaptations serve to get species out of competition with one another. He explains the mechanism thus:

"Among any group of polylectic species competing with one another for pollen supplies, one species will in all probability be at least slightly better adapted for obtaining its pollen from one flower, while others will be better adapted to other flowers. For example one species is better adapted for obtaining pollen from flower A than from other flowers, while a second species is better adapted to flower B. In this instance individuals of the first species visiting flower $B$ will be at a disadvantage as compared to those visiting flower A because of the potent competition of the second on the flower to which it is best adapted. Therefore, the bulk of reproduction of the first species will be by individuals obtaining pollen from flower $A$, that is, selection will be against those visiting flower B. If, because of inherited characteristics or preimaginal conditioning, bees that visit flower A tend to produce offspring that visit flower A, there will be a tendency for the first species to restrict itself to flower A. Thus competition between the species is reduced. If, by a like process, the second species restricts itself to flower B, the two species are no longer in competition with each other."

However, although oligolecty may be beneficial to the species which exhibits it, it is not necessary that this be so. Like other adaptations it is probably perfected because of advantages provided to certain individuals of a species in competition with members of their own species.

Linsley and MacSwain (1958a, $b$ ) have emphasized that oligolecty, used in connection with a knowledge of mating habits, provides explanations for many evolutionary phenomena in the bees. To oversimplify, it permits the survival of large numbers of species in those groups which have this characteristic (e.g. most Perdita, many Andrena) by assuring that in years of pollen shortage, competition for what is available will be among members of the same species. In years when the appropriate pollen is completely lacking, the less adaptable species will become locally extinct, fragmenting the species geographically and setting the stage for geographic speciation resulting in closely related allopatric species with the same pollen plant (e.g., many Andrena, Diadasia, Perdita). With the breakdown of geographical barriers permitting these species to come together, the result is a group of closely related sympatric species with the same pollen plant. (If this situation is to remain relatively stable, some means will presumably be developed for lessening or minimizing the resultant competition for food; in Onagrandrena and certain species Ptilandrena this is accomplished by a partial division of the 
diurnal period in which the pollen is available.) On the other hand, the adaptable species (for example, one without specialized pollen-collecting apparatus), or preadapted species, will presumably be able to change its food habits and, if the flowers are also the site for mating, isolation may become effective and provide a mechanism for speciation resulting in closely related sympatric species with quite different pollen plants. Thus, in Diadasia, although the majority of the North American species collect pollen almost exclusively from Malvaceae, $D$. enavata Cresson is restricted to Compositae, $D$. angusticeps Cockerell to Onagraceae and D. bituberculata Cresson to Convolvulaceae, suggesting sudden and abrupt changes in pollen hosts. The first two species exhibit morphological adaptations of the tibial scopa for the gathering and carrying of pollen grains from their respective sources. $D$. bituberculata, on the other hand, has elongated mouthparts suitable for extracting nectar from the deep flower of its pollen plant (Convolvulus). Linsley and MacSwain have shown that at least one species of Diadasia will turn to distantly related plants in the face of a local shortage of their usual pollen. They found a female of $D$. australis Cockerell taking pollen from Phacelia when that from the few available blooms of cactus (its regular source) had been exhausted.

Aside from its evolutionary significance, a knowledge of oligolecty is necessary for the intelligent assessment of bee species for possible introduction (Hurd and Michener, 1955).

\section{INFLUENCE OF PHYSICAL FACTORS ON THE FLIGHT OF SOLITARY BEES}

The complex of interacting physical factors which determines the periods of activity of a species of solitary bee has not been determined, and few precise data relating to the subject appear to be available. However, a few generalizations are possible. (Fig. 2.)

Sunlight. Generally speaking bees are sun-loving insects and in many species the shading of burrow entrances retards or alters activity. Even those species which are normally active early in the season (e.g., certain Andrena), when days are subject to the sudden appearance of clouds, will usually curtail activity or rest on the flowers when the sun is obscured. If the cloudy period is prolonged the females return to their burrows and the males may seek shelter. Since rain is detrimental to bees and can be disastrous to individuals trapped upon the flowers (Perkins, 1919), this behavior may be an adaptation to minimize this possibility. However, crepuscular and matinal species are often in flight during cloudy weather and social bees (Apis and Bombus) generally remain active if the temperature is not too low. In coastal areas subject to frequent fogs, species of Andrena that would not tolerate such conditions inland will remain active on foggy days (G. E. Bohart, in litt.).

Wind. Wind generally interferes with the flight of insects, but unless it is exceptionally strong or cold, most diurnal solitary bees will continue flight if the sun is bright, although their efficiency in the collection of pollen and nectar may be greatly reduced. Michener and Rettenmeyer (1956) state that 


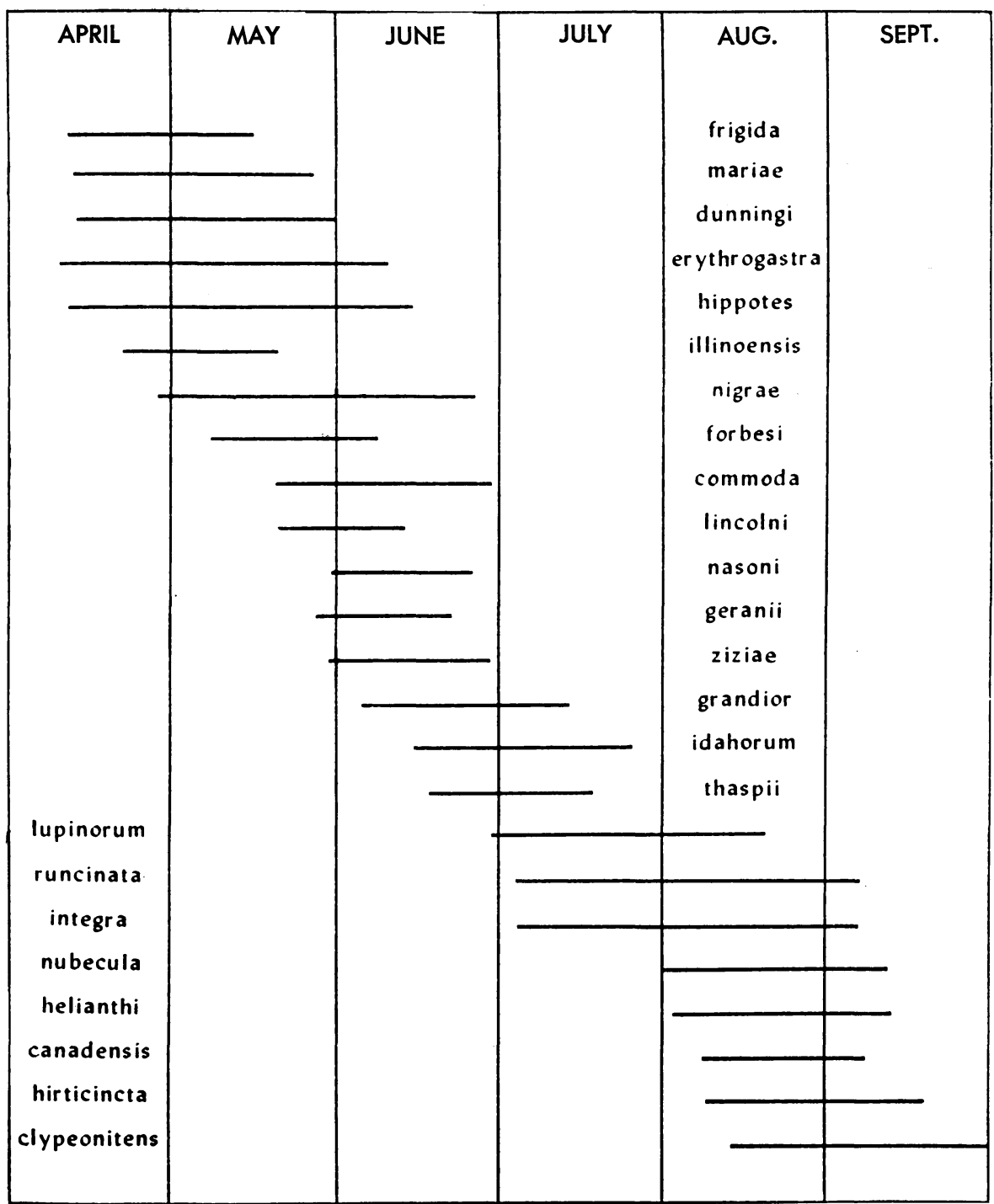

Fig. 2. Flight period of the commoner species of Andrena in North Dakota (extreme dates) (after Stevens, 1948).

Andrena erythronii Robertson is active even on windy days if the temperature is high. Robertson (1888) remarks that while wind requires bees to face it and thus alters their pattern of flight, it may compensate for this disadvantage by carrying the odors to them and by turning the flowers so that they are more easily seen and visited.

Temperature. Some data are available on the relation of temperature and the flight and activities of solitary bees. The most critical low temperature situations are faced by the bees with the earliest season (Ulrich, 1933). 
Michener and Rettenmeyer (1956) have recorded certain temperatures in relation to the activity of Andrena erythronii Robertson, a species which flies so early that snow commonly falls after the first individuals have emerged. Apparently maximum air temperatures must be in the upper $50^{\circ} \mathrm{F}$

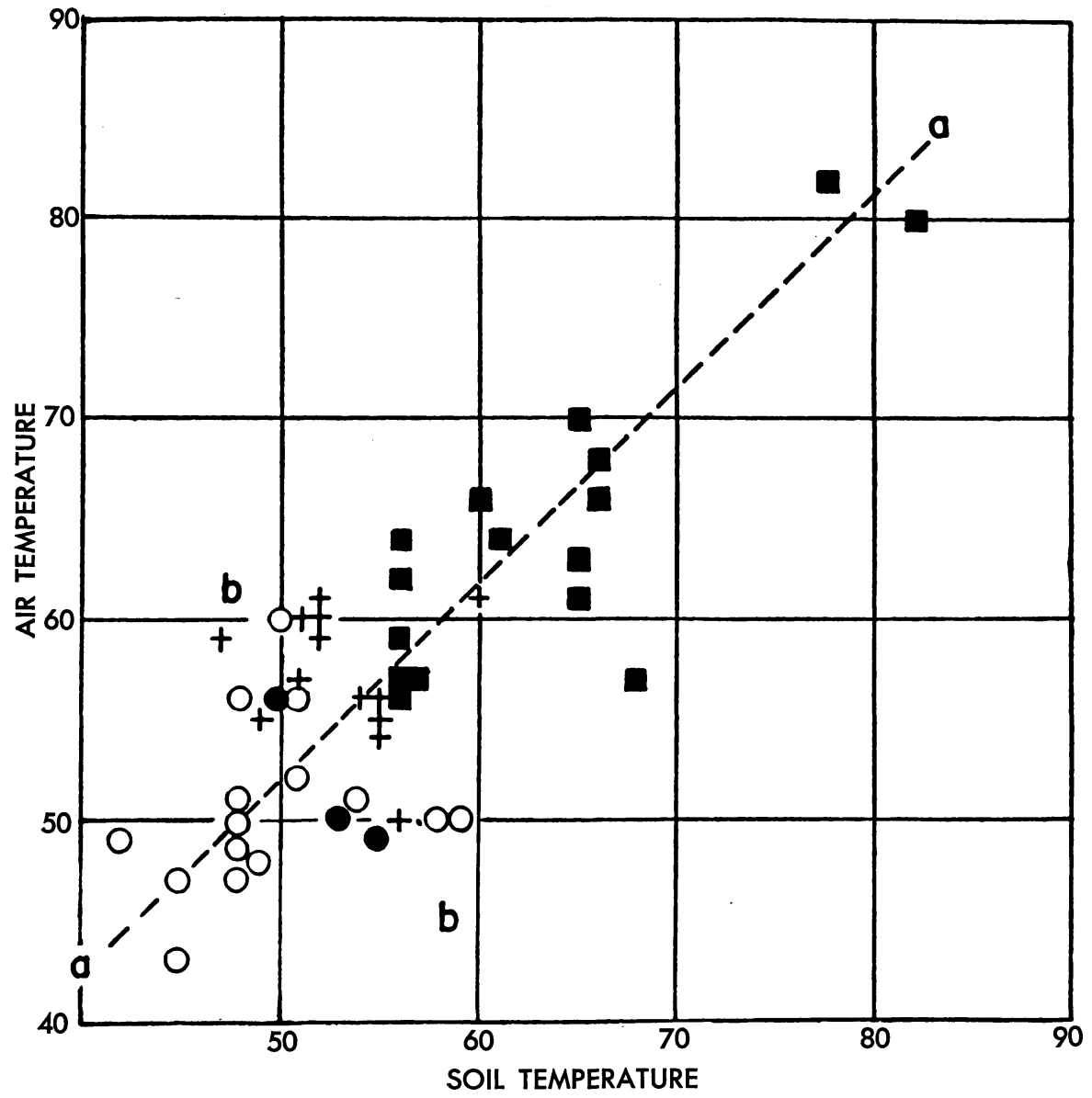

Fig. 3. Records of simultaneous air and soil temperatures (F) and activity of Andrena erythronii. Open circles indicate no activity. Squares indicate many bees flying. Beginning of activity is shown by closed circles (bees at surface but not flying) and crosses (only one or two flying in a 15-minute period). (Michener and Rettenmeyer, 1956.)

if flight is to occur, although occasional flights took place when air temperatures taken at the nesting places (in open shade ten centimeters above the ground) are $50^{\circ}$ F. Even between 10:00 A.M. and 2:00 P.M., on clear or partly cloudy days, complete inactivity occasionally occurred at air temperatures as high as $60^{\circ}$; occasional, usually short, flights occur from $50^{\circ}$ to $64^{\circ}$; while regular and extensive flights occur from $55^{\circ}$ to $80^{\circ}$. These authors considered that variation in the type of activity which occurred at an air temperature of, for example, $55^{\circ}$, was caused by factors such as 
surface temperature, soil temperature, wind, and light. Their data on surface and soil temperatures as would be expected, indicate that the range of surface temperatures is higher than the air temperatures, that of soil temperatures lower, when activity occurs. Since females survive later in the spring and thus into warmer weather than males, their temperature range extends higher. While both sexes are active the temperature factors influencing flight probably affect them similarly. The impression that males fly at lower temperatures was not supported by their data.

Simultaneous records of air and soil temperatures are summarized by Michener and Rettenmeyer in figure 3. They emphasize the occurrence of all the points about the line a-a (fitted by eye) reflects the expected correlation between air and soil temperature. The points indicating slight activity (crosses and solid circles) are concentrated in the region $b-b$, where the points are particularly widely scattered about the axis a-a. They suggest that this may be because slight activity often occurs at times of temperature change when the air temperature is rising above that of the soil or dropping beneath that of the soil.

Michener and Rettenmeyer were unable to find significant correlations between temperature or time of day and the duration of the pollen collecting trips of Andrena erythronii. However, Linsley and MacSwain (1946) noted an apparent relation between air temperatures and tripping rates for solitary bees visiting alfalfa.

Variations in temperature resulting from different exposures of nesting areas to the sun have, as would be expected, an influence on the diurnal and seasonal activity of bees. For example Vleugel (1947) states that in Holland aggregations of Andrena vaga Panzer on southeast slopes of dikes became active earlier in the spring, and the males disappeared earlier, than those on west slopes. Those on southeast slopes became active earlier in the morning and ceased activity earlier in the afternoon than those on west slopes. Unfortunately, he gave no actual temperature data.

\section{INFLUENCE OF PHYSICAL FACTORS ON BEE POPULATIONS}

The precise effects of physical factors of the environment on populations of solitary bees are not known. Most information on the subject is observational and, as in the case of the influence of physical factors on activity, precise data are generally lacking.

Low Temperature. Rau (1933) has correlated severe winters at St. Louis, Missouri, with marked reductions in local carpenter bee populations. He states that hedges of California privet at the Missouri Botanical Garden were killed by cold in the winters of 1917-18, 1923-24, and 1929-30, coinciding with years of low Xylocopa populations. Average temperatures for these winters were normal but minimum temperatures were very different. A minimum of $3^{\circ} \mathrm{F}$ was recorded for the winter of 1921-22 preceding a spring of $X$ ylocopa abundance, a minus $13^{\circ} \mathrm{F}$ in the winter of 1929-30 preceding reduced populations (down 84 per cent in a group under observation). 
Unseasonal Rainfall. Perkins (1919) has commented upon the disastrous effect of unseasonal rainfall on male bees, and Rau (1935) has described the destructive effects of heavy rainfall during the nesting period of Andrena erythrogaster (Ashmead). In the former case the bees were knocked to the ground and coated with mud or drowned. In the latter case the tumuli were beaten flat and the burrow openings covered with mud. Generally, however, excessive or unseasonal rainfall favors entomophagous or saprophagous fungi which destroy bees directly or indirectly in their burrows (Linsley and MacSwain, 1942b).

Cockerell (1936) reports that the winter and spring of 1934-35 were abnormally cool and wet in California and that the desert flora blossomed as it had not done for years. However, solitary bees were very searce, and he comments on the paradox of weather which was so favorable to the plants but so unfavorable to the emergence and flight of their pollinators. Similar observations were made by the writer the same year at Los Angeles, and a rough attempt was made to correlate bee abundance with rainfall and other records during three successive seasons. The winter of 1934-35 was wet (21.66 inches rain); the next winter was unusually dry (12.7 inches rain), flowers were uncommon, yet bees were excessively numerous. During the winter of 1936-37, a record rainfall occurred (22.41 inches), the hillsides bloomed, and once again bees were very scarce.

The obvious explanation would seem to be that in years when flowers abound the bee fauna is so scattered that individuals are difficult to locate. This must, however, be only a partial explanation. Bees which are oligotropic visitors of perennial plants (except those xerophytic species which bloom sparingly or not at all in very dry years) should be more or less equally numerous in wet and dry seasons. This, however, does not seem to be the case, and many southern California bees which gather pollen only from Salix, Ceanothus, et cetera, are scarce in wet seasons. Likewise, if numerical variations were merely due to scattering, one would anticipate the same fluctuations in the numbers of honey bees encountered (allowing for commercial movements of apiaries, et cetera). Actually, although fewer honey bees are seen when flowers are plentiful (probably an effect of scattering) they are proportionately far more numerous than the solitary bees. Finally, colonies of Andrena which were under observation, were large and very active in 1936 (a dry season) and yet were reduced to a bare minimum in 1937 (possibly due to losses from molds).

The fact that in some situations a dry year following a moist one can result in large numbers of bees and a wet season after a dry one can have the opposite effect, suggests that in unfavorable years these bees wait over, remaining dormant in their burrows until a more favorable season. Since the fall and winter are normally passed as dormant larvae (in Andrena, however, as adults) this explanation does not seem unreasonable, and under laboratory conditions this actually occurs with some individuals. Another possible explanation is that in wet years, when flowers are more numerous, the bees ean gather more pollen with less effort, making possible a large brood the following year. However, this would hardly apply in the case of species visiting perennials, as these usually nest near the plants and one 
season is presumably no more favorable than another in this respect. Mean temperatures during the active period of the bees did not favor the spring season of 1936, and the number of cloudy days during the flight period which might be expected to exert an influence on the brood of the following year, was nearly as great in the wet spring of 1935 and the dry one of 1936, yet the broods of the following seasons were vastly different. It was therefore tentatively concluded that moisture probably has the greatest influence of any physical factor upon the seasonal abundance of early spring bees in the mild climate of the area. In arid regions, during years of no rainfall, emergence may be limited or prevented by dry soil conditions. When a nesting site of Nomia melanderi Cockerell in Utah dried up, many of the emerging bees had deformed wings and poor color (G. E. Bohart, in litt.).

\section{PARASITES, PREDATORS, INQUILINES, AND FOOD DEPREDATORS}

Among the many organisms which directly or indirectly destroy solitary bees, the majority are insects. Clausen (1940) has provided an excellent summary of information on most of these. Literature cited in this section is limited largely to papers which have appeared subsequently. For convenience the species will be discussed on the basis of whether they affect primarily the larvae or the adults.

Organisms Affecting the Larvae. Various creatures are intimately associated with burrows of solitary bees. Four principal groups can be recognized by the degree of parasitic or predatory relationship and the particular food habit (Linsley and MacSwain, 1958a): (a) those which in the first larval instar prey upon the egg and in subsequent instars feed upon the stored pollen and nectar; $(b)$ those which parasitize or prey upon the developing or full-grown larva; $(c)$ those which depredate the stored pollen and nectar and destroy, modify, or starve the larva to death; and $(d)$ those which feed upon the contents of old cells and burrow refuse and only through accident have an adverse effect upon the host bee.

The first category includes several genera of so-called "parasitic," "cuckoo," or "inquilinic" bees (Friese, 1888; Wheeler, 1919; Richards, 1949; Grütte, 1935) and a few groups of meloid beetles (MacSwain, 1955). The bees oviposit directly in the cell of the host species, and the various genera are usually associated with definite host genera or groups (table 4) and the individual species may be highly specific. The meloid beetles do not oviposit directly in the cell of the host bee. Some (e.g. Nemognatha, Zonitis) place their eggs upon certain flowers and the newly hatched larvae cling to the bee as it visits the flower and are transported back to the nest (Linsley and MacSwain, 1952a; Selander and Bohart, 1954). Species in these genera may have few or many diverse hosts, depending in part upon the attractiveness of the plant selected to suitable bees. Others (e.g. Tricrania) oviposit in or near the nesting site and depend upon the larvae to attach themselves to a suitable host (Linsley and MacSwain, 1951). Although not host-specific, this habit further restricts the number of available hosts. A few (e.g. Cissites, Hornia, Allendesalazaria) oviposit in the natal cell or adjacent burrows 
TABLE 6

ESTABLISHED AND PRESUMED GENERIC HOST RELATIONSHIPS FOR NORTH AMERICAN GENERA OF "PARASITIC" BEES*

(Extracted from Linsley and Michener, 1939; and Michener, 1944, with additions)

\begin{tabular}{|c|c|c|c|}
\hline Family & Genus & $\begin{array}{l}\text { Family or } \\
\text { subfamily }\end{array}$ & Genus \\
\hline Halictidae. . & Sphecodes & $\begin{array}{l}\text { Halictidae } \\
\text { Halictidae }\end{array}$ & $\begin{array}{l}\text { Halictus } \\
\text { Lasioglossum* }\end{array}$ \\
\hline Megachilidae. & Stelis & $\begin{array}{l}\text { Megachilidae } \\
\text { Megachilidae } \\
\text { Megachilidae }\end{array}$ & $\begin{array}{l}\text { Heriades } \\
\text { Hoplitis } \\
\text { Osmia* }\end{array}$ \\
\hline Megachilidae. . & Chelynia & $\begin{array}{l}\text { Megachilidae } \\
\text { Megachilidae } \\
\text { Megachilidae } \\
\text { Megachilidae } \\
\text { Megachilidae }\end{array}$ & $\begin{array}{l}\text { Anthidium } \\
\text { Ashmeadiella* } \\
\text { Heriades } \\
\text { Hoplitis } \\
\text { Osmia }\end{array}$ \\
\hline Megachilidae. & Dioxys & $\begin{array}{l}\text { Megachilidae } \\
\text { Megachilidae } \\
\text { Megachilidae } \\
\text { Megachilidae } \\
\text { Megachilidae } \\
\text { Megachilidae } \\
\text { Megachilidae }\end{array}$ & $\begin{array}{l}\text { Callanthidium* } \\
\text { Anthidium } \\
\text { Hoplitis* } \\
\text { Diceratosmia* } \\
\text { Osmia } \\
\text { Anthocopa* } \\
\text { Megachile }\end{array}$ \\
\hline Megachilidae... & Coelioxys & Megachilidae & Megachile \\
\hline Anthophorinae.. & Nomada & $\begin{array}{l}\text { Andrenidae } \\
\text { Halictidae } \\
\text { Halictidae }\end{array}$ & $\begin{array}{l}\text { Andrena } \\
\text { Halictus } \\
\text { Nomia }\end{array}$ \\
\hline Anthophorinae. . & Hexepeolus & Andrenidae & Ancylandrena* \\
\hline Anthophorinae. & Paranomada & Anthophorinae & Exomalopsis* \\
\hline Anthophorinae. . & Hesperonomada & Anthophorinae & Exomalopsis* \\
\hline Anthophorinae.... & Holcopasites & $\begin{array}{l}\text { Andrenidae } \\
\text { Andrenidae }\end{array}$ & $\begin{array}{l}\text { Pseudopanurgus } \\
\text { Calliopsis }\end{array}$ \\
\hline Anthophorinae. . & Neopasites & Halictidae & Dufourea \\
\hline Anthophorinae. . & Townsendiella & $\begin{array}{l}\text { Halictidae } \\
\text { Halictidae }\end{array}$ & $\begin{array}{l}\text { Conanthalictus } \\
\text { Hesperapis }\end{array}$ \\
\hline Anthophorinae. & Neolarra & Andrenidae & Perdita* \\
\hline Anthophorinae. & Oreopasites & Andrenidae & Nomadopsis \\
\hline Anthophorinae... & Epeolus & Colletidae & Colletes \\
\hline Anthophorinae...... & Triepeolus & $\begin{array}{l}\text { Anthophorinae } \\
\text { Anthophorinae } \\
\text { Anthophorinae }\end{array}$ & $\begin{array}{l}\text { Melissodes } \\
\text { Svastra } \\
\text { Anthophora }\end{array}$ \\
\hline Anthophorinae. & Epeoloides & Melittidae & Macropis \\
\hline Anthophorinae. & Melecta & Anthophorinae & Anthophora \\
\hline Anthophorinae. & Xeromelecta & Anthophorinae & Anthophora \\
\hline Anthophorinae... & Zacosmia & Anthophorinae & Anthophora \\
\hline 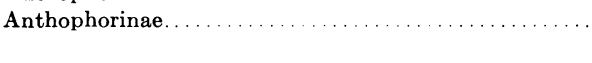 & Ericrocis & $\begin{array}{l}\text { Anthophorinae } \\
\text { Anthophorinae }\end{array}$ & $\begin{array}{l}\text { Centris } \\
\text { Anthophora }\end{array}$ \\
\hline & Mesoplia & Anthophorinae & Centris \\
\hline Apidae. & Psithyrus & Apidae & Bombus \\
\hline
\end{tabular}

* Presumed relationships are indicated by an asterisk $\left({ }^{*}\right)$. No data are available for Heterostelis (Megachilidae) or for Triopasites, Melanomada, Protepeolus or Brachymelecta (Anthophorinae).

and the larvae attach themselves to bees active in the site (Linsley and MacSwain, 1942c). This method not only greatly reduces the number of hosts but limits them to species of gregarious nesting habit. Such meloids are often highly host-specific.

The second category, comprising species which parasitize or prey upon the developing or full-grown larvae, is much more diverse. Two families of beetles (Rhipiphoridae, Stylopidae) are endoparasitic during all or part 
of the larval development (Linsley, MacSwain, and Smith, $1952 b$; Linsley and MacSwain, 1957), and since the larvae gain access to the host on the flowers, the degree of host specificity, like that in Nemognatha, depends to some extent upon the nature of the visitors to the particular flowers concerned rather than to the nesting habits of the bee. However, within this range relatively high specificity is apparent. Among clerid beetles which place their eggs on flowers (e.g. Trichodes), some species use little discrimination in the kinds of flowers selected and thus infest a wide variety of bees and wasps with diverse nesting habits and exhibit little specificity (Linsley and MacSwain, 1944), and others seem to be more restricted (G. E. Bohart, in litt.). Certain meloids (e.g. Meloe, Lytta) oviposit in the soil in the nesting area. In the former genus the larvae climb plants and attach to adult bees, in the second genus they find their way into appropriate burrows. This habit restricts them to hosts which are abundant in a local site. Bombyliid flies (e.g. Villa, Anthrax), mutillid wasps (e.g. Photopsis) and certain mantispid neuropterans (e.g. Plega), oviposit in or near the burrows of their hosts and are commònly associated with gregarious species (Bezzi, 1924; Painter, 1932 ; Linsley and MacSwain, 1942, 1955). Larvae of the asilid genus $H y$ perechia are external parasites of Xylocopa (Poulton, 1924; Engel, 1929) and those of the sarcophagid genus Brachioma on bumble bees. Metopia leucocephala Rossi, however, occurs on Lasioglossum pruinosum (Robertson) (Melander and Brues, 1903). Sapygid wasps (Linsley, 1944b; Pate, 1947), chrysidids (Maneval, 1932 ; Hicks, 1933), leucospids (Graenicher, 1906a), and the pteromalid Epistenia osmiae (Ashmead) also oviposit in the cells of their hosts but are limited mainly to the solitary nests of megachilids. although within this group they are not usually species-host-specific and are often wide ranging geographically. Twig-nesting species (e.g. Ceratina, Heriades, Hylaeus) are especially susceptible to parasitism by Hymenoptera. Among the parasites involved in this habitat are Gasteruption (Höppner, 1904 ; Rau, 1928), the ichneumonids Grotea (Rau, 1922), Holocryptus gracilis (Provancher) (Viereck, 1916), Melittobia (Packard, 1865 ; Balfour-Browne, 1922), the torymid Diomorus zabriskiei Cresson and the eurytomid Axima zabriskiei Howard. The torymid genus Monodontomerus, however, parasitizes larvae of bees which nest in a variety of habitats and the related Microdontomerus is associated with the resin nests of Dianthidium. The diapriid Acidopria columbiana (Ashmead) infests the gregarious nests of Lasioglossum pruinosum (Robertson) (Melander and Brues, 1903).

Depredators on the larval food of bees include several genera of megachilids (e.g. Stelis, Dioxys, Coelioxys) ${ }^{9}$ (Graenicher, 1905b, 1927 ; Michener, 1953b, 1955a ; Popov, 1953 ; Hurd, 1958), ptinid beetles (esp. Ptinus) (Linsley and MacSwain, 1942), phorid flies (Borgmeier, 1925 ; Salt, 1929; Linsley, 1945), certain mites (Salt, 1929; Malyshev, 1931), and various kinds of molds (Linsley and MacSwain, 1942; Bohart and Cross, 1955). The latter are of common occurrence, but their role has not been evaluated. Several species of Ptinus occur regularly in bee nests and some of these are apparently associated primarily with species of Osmia. Bohart (1949) has recorded a fungus outbreak in adult bees. The mites associated with nests of solitary

\footnotetext{
" These, however, usually kill the bee larva at an early stage of development.
} 
bees have not been well studied, but since they are transported on the bodies of the bees (Rayment, 1954a; Hirashima, 1957) they may be somewhat hostspecific. Although the acarines in bees' nests have been generally regarded as food depredators, Lith $(1957 b)$ has shown that Chaetodactylus osmae (Dufour) and its relatives actually kill the bee larvae before turning to the stored pollen. Vitzhum (1930) has described seven species from nests of stingless bees.

Scavengers in the old burrows of solitary bees and sometimes on fresh pollen include dermestids (e.g. Trogoderma, Anthrenus), certain flies (e.g. Hylemya cilicrura Rondani, Pegomyia affinis Stein, and Megaselia spp.), moths (e.g., Bitula, Tineola), and various stored product pests (e.g., Stegobium, Tribolium, Plodia) (Linsley, 1942, 1944). Some of these (e.g., the dermestids) may open freshly provisioned cells and others (e.g., the flies) may infest newly stored pollen. In general, however, their activities are limited largely to sites of gregarious nesting species. Scavenging beetles are particularly numerous and varied in the nests of social bees (Salt, 1929; Plath, 1934).

Briefly, it would appear that the greater number of parasites, predators, depredators, and scavengers are associated with gregarious nesting, solitary bees, especially Anthophoridae, and that the most distinctive complex of parasitic forms is that associated with the Megachilidae.

Predators and Parasites of Adult Bees. Insect predators of adult bees belong largely to the robber fly family Asilidae and the philanthine and cercerine wasps of the family Sphecidae and the reduviid bugs of the Apiomerinae and Ectinoderinae, although many other groups are involved. The asilids (robber flies) are better known as predators of honey bees (Bromley, 1930 ; Hobby, 1931). Several genera (e.g. Stenopogon, Diogmites, Promachus, Mallophora, and Proctacanthus) commonly prey upon bees. In North America, Promachus fitchii Osten Sacken has been called the "Nebraska bee-killer." Protacanthus milbertii Macquart as the "Missouri bee-killer," Mallophora orcina Wiedemann and $M$. bomboides Wiedemann as the "Southern beekillers" and Saropogon dispar Coquillett, Diogmites angustipennis Loew and D. symmacha Loew as "Texas bee-killers." Species of Mallophora and Bombomima are robust and hairy and resemble bumble bees, upon which they prey, but not exclusively. The former genus has been reported as an enemy of honey bees in Argentina and Cuba as well as North America. Among the North American species which prey to some extent on solitary and semisocial bees may be mentioned Saropogon dispar Coquillett (Halictidae, Andrenidae), Diogmites texanus Bromley (Halictidae), D. symmachus Loew (Anthophorinae, Andrenidae), D. angustipennis Loew (Halictidae), D. umbrina Loew (Andrenidae, Halictidae, Megachilidae), Proctacanthus philadelphicus Macquart (Anthophorinae, Andrenidae, Halictidae), Promachus bastardi Macquart (Halictidae), P. fitchii Osten Sacken (Andrenidae, Megachilidae, Halictidae), and $P$. rufipes Wiedemann ("solitary bees"), Callinicus calceaneus Loew (Megachilidae, Andrenidae) (Linsley, $1944 a$ ). The prey of 22 specimens of this last species were examined, and nearly three fourths consisted of brightly colored species of Osmia, the remainder of dull-colored Andrena spp., although the latter outnumbered the 
former by about five to one on the flowers where the robber flies were capturing them (Linsley, 1944). G. E. Bohart (in litt.) reports that attempts to follow marked bees in Utah were interfered with by species of Promachus and Proctacanthus which swooped down upon the brightly marked individuals.

The Apiomerinae of the New World and Ethiopian region include many species which lie in wait for bees upon the flowers, capturing them by means of the front legs, aided by sticky materials. Miller (1956) comments that the habit of covering the anterior tibiae with a resin for the purpose of capturing prey is characteristic of some members of this subfamily. Specimens are often found to have a considerable amount of debris adhering to them on account of a glutinous material on their legs and body. Whether this substance is secreted by the insect or is deliberately collected by it is uncertain. The actual collection of a resinous substance by a member of this subfamily was observed in Surinam by Uittenboogaart (1901). With regard to the Ectinoderinae, Miller (1956) remarks that Amulius and Ectinoderus, which are found in the Oriental Region, make use of resins produced by certain trees which they smear on their anterior tibiae and utilize to capture small insects-usually bees of the genus Trigona-which become entangled like a fly on flypaper. Usinger (1958), in Thailand, reports Ectinoderus longimanus Westwood and Amulius malayus Stål lying in wait at the edges of resin pools in trunks of Dipterocarpus alatus for Trigona (Tetragona) iridipennis F. Smith, which swarmed about them.

Depredations of specid wasps of the genus Philanthus are best known in relation to honey bees (Fabre, 1891; Thiem, 1935; Olberg, 1953), and the common European species, $P$. triangulum Fabricius, is known as the "bee wolf." The wasps sting their prey in the throat which they then malaxate, feeding on the honey from the crop. The bee is then dragged to the burrow and stored in a cell with others to provide food for the larvae. The best known North American species, P. gibbosus Fabricius, provisions largely with halictines (e.g. Augochlora, Halictus, Lasioglossum, Evylaeus, Curtisapis, Oxyglossa, Seladonia, and Dialonia) but also utilizes the panurgid Calliopsis andreniformis Smith (Reinhard, 1924). The genus Cerceris is largely predaceous on Coleoptera (Linsley and MacSwain, 1955), but several species, including the European C.rybiensis (Linnaeus), prey upon halictine bees. Their habits are similar to those of Philanthus, and the females likewise perform extensive malaxation of the throat after stinging the prey (Maréchal, 1887). Other predators on adult bees include crab spiders and flower-inhabiting phymatid bugs (Balduf, 1939-43). In nesting sites they are also preyed upon by Cicindela tiger beetle larvae and adults (Frick, 1957).

Parasites of adult bees are almost exclusively flies. Among these are the phorid Melaloncha ronnai Borgmeier which oviposits in the abdomen of the bee during flight, and the larva destroys the bee and pupates in the thorax (Ronna, 1937). The sarcophagids Senotainia and Myiapis have similar habits (Seguy, 1930; Simintzis and Fiasson, 1951), the larvae feeding in the thorax. However, larvae of the tachinid Rondanioestrus, which larviposits on bees in flight, feed in the abdomen (Skaife, 1921). Probably the most important of the dipterous parasites of adult bees are conopids, which also 
oviposit on the host in flight, destroy the body contents, and pupate in the dead shell. Most of the recorded hosts for European species and for several of the North American forms are bumble bees. However, Physoconops has been associated with Megachile, Myopa with Andrena and Anthophora, Physocephala with Anthidium, Anthophora, Eucera, Megachile, Halictus, Bombus and Apis, and Zodion with Hylaeus, Panurginus, Nomia, Halictus and Apis (de Meijere, 1903, 1912; Kröber, 1919; Camras and Hurd, 1957). In spite of the generic range of hosts, MacSwain and Bohart (1947.) have reported indications of host specificity at the species level.

A symbiotic relationship apparently exists between laelaptid mites of the genus Dinogamasus (= Dolaea) and carpenter bees of the groups Mesotrichia, Koptorthosoma, Platynopoda, and Cyaneoderes (Vitzhum, 1930; Leveque, 1932). Nearly a dozen species are known to live in special pouches in the abdomen of female bees. The mites leave when nesting begins, enter the cells, and ultimately lay their eggs on the pupae. The larvae feed on exudations from the skin of the pupal bee and are mature by the time the bee transforms and they can enter the pouch (Skaife, 1952). The bees are apparently unharmed by the relationship and they derive no obvious benefit.

Role of Parasites and Predators in Population Control. Although local populations of solitary bee species are sometimes very large (Cockerell, 1933), little precise information is available indicating the role of parasites and predators in population control. What data have been published are largely expressed in terms of percentage of parasitism observed in samples taken from nesting sites or individual colonies of gregarious ground-nesting species, especially Anthophorinae (Linsley and MacSwain, 1942b), or twignesting forms, especially Osmiini (Medler, 1958). In large nesting sites, although the effects of parasitism are often noticeable, a wide variety of parasites may be tolerated. In the case of Anthophora linsleyi Timberlake, approximately 50 per cent of the larval progeny of a given season may be lost (table 7) without apparent detrimental effect upon the adult population which utilizes the site (Linsley and MacSwain, 1942b). In small sites, however, the right combination of parasites may be disastrous (table 8) and virtually exterminate a local population (Linsley and MacSwain, 1952b). However, the nature of the parasite or combination of parasites is more important than the size of the nesting site. Those which place their eggs on flowers are dependent upon the host bee visiting the flower and transporting the larvae to the nest. Thus, Rhipiphorus smithi Linsley and MacSwain, which oviposits on Sida, the pollen source for Diadasia consociata Timberlake, has a relatively long season and can infest from 15 to 30 per cent of the cells in a given area (Linsley, MacSwain, and Smith, 1952a, 1952b). Zonitis atripennis (Say), which oviposits on Cleome in certain areas, may have been an equally heavy parasite on Nomia melanderi Cockerell. However, Nomia now prefers introduced alfalfa and sweet clover, and in places where these are available parasitism by Zonitis is generally less than one per cent (Selander and Bohart, 1954). Potentially, the most effective insect parasites of gregarious ground-nesting species are probably bombyliid flies which in a Nomia colony are capable of infesting almost 100 per cent of the burrows which are open at a given time (G. E. Bohart, in litt.). However, although 
in this case the fly Heterostylum begins activity at the same time as Nomia melanderi Cockerell, the season of the latter is a little longer and thus the local population is able to avoid extermination. N. triangulifera Vachal, which nests in the same areas but starts its season late is only lightly parasitized. Thus timing is an important factor in maintaining this, as other host-parasite relationships. Stephen (1958), observing that the mature larvae of Heterostylum robustum Osten Sacken, the chief parasite of Nomia me-

TABLE 7

PARASITES, PREDATORS, AND SCAVENGERS IN NESTS OF ANTHOPHORA LINSLEYI TIMBERLAKE AT TWO CALIFORNIA LOCALITIES

(After Linsley and MacSwain, 1942b)

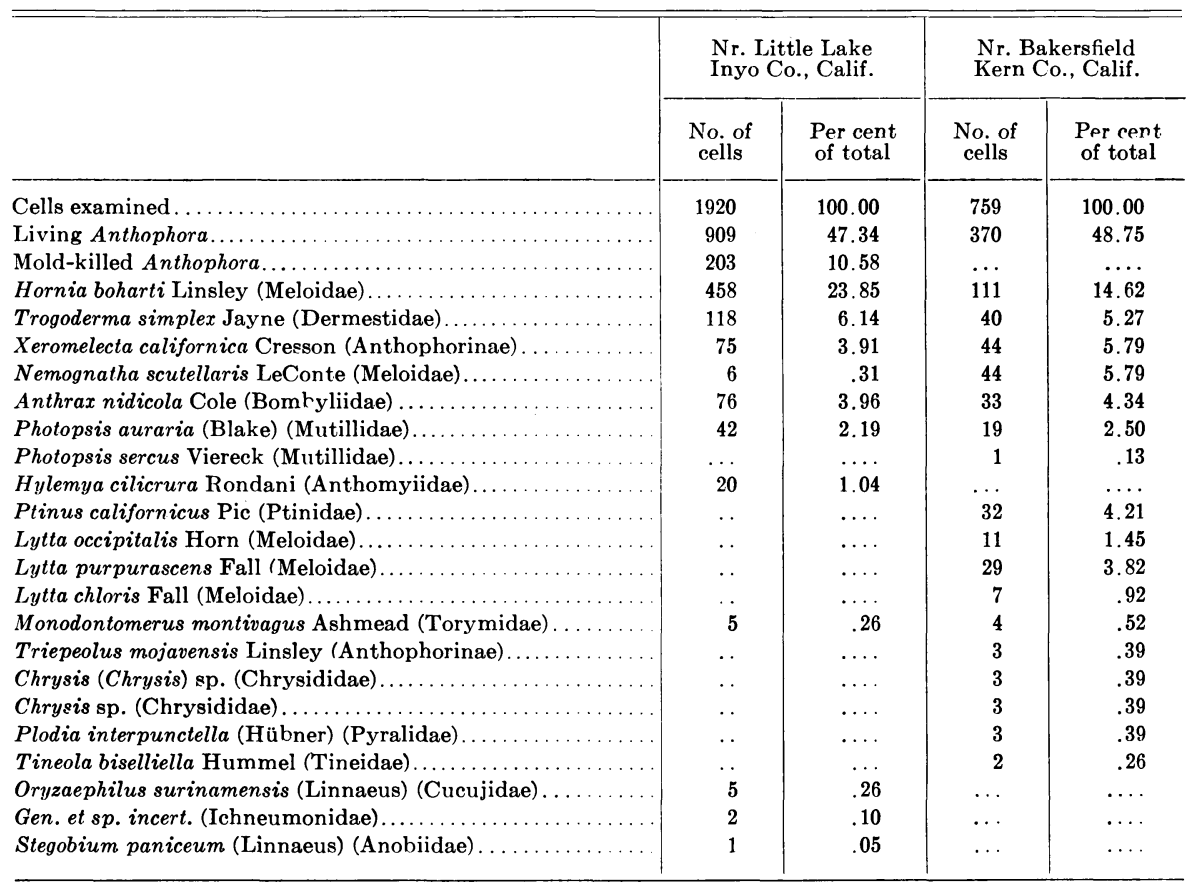

landeri Cockerell in Oregon, move upward out of the bee cells and spend some time in the top few inches of the soil, obtained excellent control of the flies by rototilling the soil with an insecticide and then packing the soil down. Rototilling and packing were reasonably effective even without the insecticide.

Parasites which oviposit in the nests of nongregarious species (e.g. Coelioxys, Stelis, Nomada) learn to recognize certain nests and return to them repeatedly (Graenicher, 1906b ; Michener, 1953b, 1955; Linsley and MacSwain, 1955a) resulting in a very high percentage of parasitism in certain nests and cell series, a complete absence of parasites in others. Also, the searching pattern of such species may limit the nests which can be parasitized. Coelioxys octodentata Say is an important parasite of Megachile brevis Say, a species which nests commonly in dead stalks but also in other habitats as 
holes in wood or soil, under stones, matted grass, et cetera. However, Michener $(1953 b)$, in the course of a careful study of the host species, observed Coelioxys searching only dead stalks and no parasitized cells were found in any other habitat.

The role of predators and parasites of adult solitary bees in controlling population levels is equally unclear. Bromley (1930) concludes that robber flies can rarely cause economic losses to apiarists because they are rarely

TABLE 8

PARASITES AND PREDATORS IN NEST SAMPLE FROM A SMALL POPULATION OF DIADASIA BITUBERCULATA (CRESSON)

(After Linsley and MacSwain, 1952b)

\begin{tabular}{|c|c|c|c|}
\hline & $\begin{array}{l}\text { No. of } \\
\text { cells }\end{array}$ & $\begin{array}{l}\text { Per cent } \\
\text { of total }\end{array}$ & $\begin{array}{l}\text { Per cent of } \\
\text { non-moldy } \\
\text { cells }(248)\end{array}$ \\
\hline Cells sampled..... & 377 & 100.0 & 100.0 \\
\hline 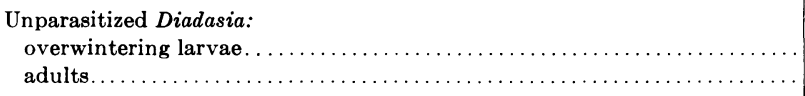 & $\begin{array}{l}32 \\
15\end{array}$ & $\begin{array}{l}12.5 \\
\cdots\end{array}$ & $\begin{array}{l}\ldots . \\
21.8\end{array}$ \\
\hline Adult Diadasia dead from unknown causes.................. & 7 & 1.9 & $\ldots$ \\
\hline Cell contents destroyed by molds........... & 129 & 34.2 & $\cdots$ \\
\hline 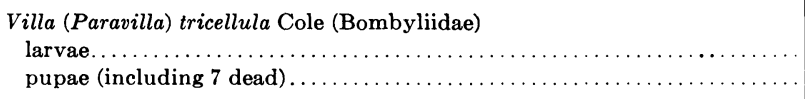 & $\begin{array}{l}84 \\
18\end{array}$ & $\begin{array}{l}\ldots . \\
27.1\end{array}$ & $\begin{array}{l}\ldots \\
41.1\end{array}$ \\
\hline 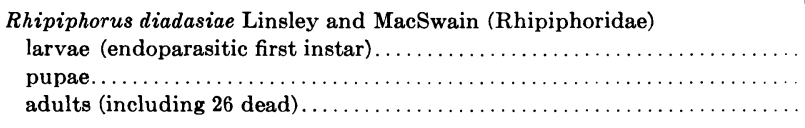 & $\begin{array}{r}12 \\
2 \\
32\end{array}$ & $\begin{array}{l}\ldots \\
12.1 \\
\cdots\end{array}$ & $\begin{array}{l}\cdots \\
18.5 \\
\cdots\end{array}$ \\
\hline 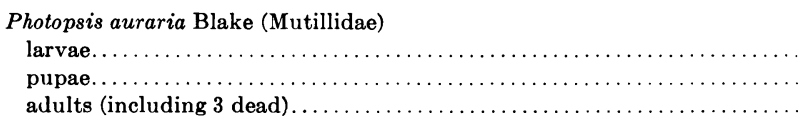 & $\begin{array}{l}5 \\
8 \\
7\end{array}$ & $\begin{array}{l}\ldots \\
5.3 \\
\cdots\end{array}$ & $\begin{array}{l}\cdots .1 \\
8.1\end{array}$ \\
\hline $\begin{array}{c}\text { Photopsis sp. (Mutillidae) } \\
\text { larvae................... }\end{array}$ & 11 & 2.9 & 4.4 \\
\hline 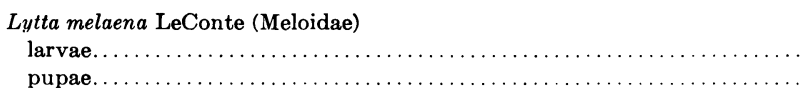 & $\begin{array}{r}11 \\
4\end{array}$ & $\begin{array}{l}4.0 \\
\cdots\end{array}$ & $\begin{array}{l}6.1 \\
\cdots\end{array}$ \\
\hline
\end{tabular}

abundant enough. However, Clausen (1940) states that the reduction in populations of wild bees through attacks of various species of Asilidae may have injurious results because of less complete pollination of blossoms. Ronna (1937) records losses of up to 50 per cent of adult bees from attacks by the phorid Melaloncha in Brazilian apiaries but what the losses might be to solitary bees under less concentrated conditions is not known. Clausen (1940) states that the comparative scarcity of the Conopidae gives them relatively little importance, although he grants that their attacks on bumble bees may reduce pollination. However, Bohart and Cross (1955), in part, attribute deceleration in nest construction by Nomia melanderi Cockerell to para- 
sitism of adult females by larvae of Zodion obliquefasciatum Macquart, the developing larvae of which progressively starve the ovaries and then crowd them out.

The Effects of Parasitism on Behavior of Bees. Most of the parasites of adult bees have visible effects upon the behavior of their hosts, but none have been so thoroughly studied as those of the genus Stylops in bees of the genus Andrena (Pérez, 1886; Pierce, 1909; Wheeler, 1910; Smith and Hamm, 1914 ; Perkins, 1918; Salt, 1927, 1931; Clausen, 1940 ; R. M. Bohart, 1941). These parasites frequently bring about reduction in the size of the head, enlargement of the abdomen, disturbances in wing venation, abnormal puncturation and pilosity, and a reversal of the secondary sex characters. Sexual dimorphism is normally very pronounced in Andrena. The males may have a larger head with a yellow clypeus; always possess an additional segment in the abdomen and usually in the antennae; and slender legs which are devoid of pollen-collecting apparatus, et cetera. Any reversal of secondary sexual characters is pronounced, and a conspicuous intersex may be produced. Internal effects of stylopization mainly involve the gonads. In the female these are usually reduced to a point where the bee is incapable of reproduction. In the male, the reduction usually involves only one side, and ripe sperm still may be available. In general, the parasitized forms emerge early, permitting mating, eclosion of the eggs and larviposition on the flowers to take place in time for the main pollen collecting season of the host. Usually the sex instinct is not destroyed in either the male or the female, although the latter is usually incapable of reproduction. The pollen collecting instinct is usually lacking, although the bees frequent flowers and thus infect them with parasite larvae. All of the effects of stylopization are increased when the parasite is a male, regardless of the sex of the host. Smith and Hamm regard it as possible that the presence of the male Stylops (since it undergoes complete metamorphosis) has a more generally damaging effect on the bee, but there is no evidence of the male parasite exciting a specific male effect and the female exciting a female effect upon the host. Salt, in an extensive study of the effects of stylopization, explains them on the basis of nutrition. He points out that stylopized bees are intersexes, and that presumably the abstraction of nourishment by the parasite removes essentials from the host which upset the reaction of hormones. His assumption is based on the fact that in Andrena the effect of the male parasite is greater than the female (apparently the result of the extraction of more nutritive material from the host). In Polistes, however, where the larvae are fed progressively and not forced to survive upon a limited amount of food, the effect of the male parasite is no greater than that of the female (apparently because the larvae were given sufficient food to offset that required by the parasite).

\section{ACKNOWLEDGMENTS}

The helpful suggestions of G. E. Bohart, P. D. Hurd, Jr., J. W. MacSwain, C. D. Michener, Ray F. Smith, and P. H. Timberlake are gratefully acknowledged. 


\section{BIBLIOGRAPHY}

AdAms, C. C.

1915. An ecological study of prairie and forest invertebrates. Illinois State Lab. Nat. Hist. Bul. 11:33-280; 63 pls.

ÅKERBERG, E., and K. LENSINS

1949. Insects pollinating alfalfa in central Sweden. Roy. Agr. Col. Sweden Ann. 16:63043.

ALFKEN, J. D.

1935. Die Bienen Nordwestdeutschlands als Blütenbesucher. Abh. naturw. Ver. Berlin 29:193-206.

AMARAL, E.

1953. Etudos apicolas em leguminosas. Esc. Sup. Agr. "Luiz de Queiroz," São Paulo: Thesis. $60 \mathrm{pp}$.

ANDERSON, E. J., and M. WoOD

1944. Honeybees and red clover pollination. Amer. Bee Jour. 84:156-57.

ARMstrong, J. B.

1883. On the fertilization of red elover in New Zealand. New Zealand Jour. Sci. 1: $474-75,500-04$.

ARNOLD, G.

1947. A key to the African genera of the Apidae. Ent. Soc. So. Africa Jour. 9:193-218. AUTRUM, $\mathrm{H}$.

1948. Ửber Energie- und Zeitgrenzen der Sinnesempfindungen. Naturwissenschaften 35 : 361-69.

1950. Neue Versuche zum optischen Auflösungvermögen fliegende Insekten. Experientia 5:271-77.

BALDUF, W. V.

1939. Food habits of Phymata pennsylvanica americana Melin (Hemip.) Canad. Ent. $71: 66-74$.

1940. More ambush bug prey records (Hemiptera). Brooklyn Ent. Soc. Bul. 35:161-69.

1943. Third annotated list of Phymata prey records (Phymatidae, Hemiptera). Ohio Jour. Sci. 43(2):74-78.

BALFOUR-BRowne, F.

1922. On the life-history of Melittobia acasta Walker, a chalcid parasite of bees and wasps. Parasitology 14:349-69.

BANKS, N.

1908. Sleeping habit of a bee. Ent. News 19:340.

Bateman, A. J.

1947. Contamination of seed crops. I. Insect pollination. Jour. Genet. 48:257-75.

1951. The taxonomic discrimination of bees. Heredity 5:271-78.

BEAL, R. S., JR.

1956. Insects found associated with Osmia lignaria propinqua Cresson in a Colorado nesting site. Pan-Pacific Ent. 32:166.

BenoIst, $\mathrm{R}$.

1946. Les Apides (Hyménopt.) des Campanules. L'Entomologiste 2:90-93.

BERTONI, A. DE W.

1911. Contribucion à la biologia de las avispas y abejas del Paraguay (Hymenoptera). An. Mus. Nac. Buenos Aires 15(3):97-146.

BETTS, A. D.

1920. The constancy of the pollen-collecting bee. Bee World $2: 10-11$.

1935. The constancy of the pollen-collecting bee. Bee World 16:111-13.

BEzzI, M.

1924. The Bombyliidae of the Ethiopian region, based upon material in the British Museum (Natural History). London, England. 390 pp.

BINGHAM, C. T.

1897. Hymenoptera, I. Fauna of British India. London, England. 579 pp.

BISCHOFF, H.

1927. Biologie der Hymenopteren. Schoenichen Co., Berlin, Germany. 598 pp. 
Blagoveshchenskaia, N. N.

1954. On the nesting of Apidae-pollinators of lucerne [In Russian]. Dokl. Acad. Nauk. SSSR. 99:859-60.

1956. Nest-building of the solitary bees Halictus sexcinctus $F$. and Halictus quadricinctus $\mathrm{F}$. in the Ulyanovsk Region. Trans. Ulyanovsk State Pedagogical Inst. Issue 9.

BOHART, G. E.

1947. Wild bees in relation to alfalfa pollination. In Farm and Home Science. Utah Agr. Exp. Sta. 8(4):13-14.

1949. Records of a fungus outbreak among adult bees of the genus Andrena (Hymenoptera, Andrenidae). Pan-Pacific Ent. 25:82.

1950. Observations on the mating habits of halictid bees. Pan-Pacific Ent. 26:34-35.

1951. Alfalfa seed growers of Utah should protect their wild bees. In Farm and Home Science. Utah Agr. Exp. Sta. 12(2):32-37.

1953. Pollination by native insects. In 1952 Yearbook of Agriculture. U. S. Dept. Agr. Pp. 107-21.

1955. Alkali bees vs. drainage. In Farm and Home Science. Utah Agr. Exp. Sta. 16: 23-24, 39-40.

1957. Pollination of alfalfa and red clover. Annual Rev. Ent. 2:355-80.

BoHaRT, G. E., and E. A. Cross

1955. Time relationships in the nest construction and life cycle of the alkali bee. Ent. Soc. Amer. Ann. 48:403-06.

BoHART, G. E., and J. W. MACSWAIN

1940. A conopid parasite of Megachile. Pan-Pacific Ent. 16:91.

BoHART, G. E., and W. P. NYE

1956. Bees. Their place in the world of insects ... Gleanings in Bee Culture 84:265-68, 317 ; 331-33, 337 ; 400-05; 468-72, 508; 602-06, 639.

BoHART, R. M.

1941. A revision of the Strepsiptera with special reference to the species of North America. Univ. California Pubs. Ent. 7:91-160.

BoLWIG, $\mathrm{N}$.

1937. Nogle Unders $\varnothing$ gelser over den Maade, hvorpaa de enlige Bier samler Pollen. Ent. Meddel. 20:67-79.

BORGMEIER, T.

1925. Novos subsidios para o conheciemento da familia Phoridae. Arch. Mus. nac. Rio de Janeiro 25:85-281.

Bradley, J. C.

1919. An entomological cross section of the United States. Sci. Monthly 1-54.

BRITTAIN, W. H.

1933. Apple pollination studies in the Annapolis Valley, N.S., Canada, 1928-1932. Canada Dept. Agr. Bul. 162(n.s.):1-198.

BROMLEY, S. W.

1930. Bee-killing robber flies. New York Ent. Soc. Jour. 38:159-75.

BULMAN, G. W.

1892. The constancy of the bee. Sci. Gossip 329:98-99.

1902. The constancy of the bee. Zoologist 6:220-22.

BURKHILL, I. H.

1909. Insects and flowers in India. In Maxwell-Lefroy, Indian Insect Life. Pp. 222-23.

BUTLER, C. G.

1945. The influence of various physical and biological factors of the environment on honeybee activity. An examination of the relationship between activity and nectar concentration and abundance. Jour. Exp. Biol. 21:5-12.

Butler, C. G., J. B. Free, and J. Simpson

1956. Some problems of red clover pollination. Ann. Appl. Biol. 44:664-69.

BUTLER, C. G., and J. Simpson

1953. Bees as pollinators of fruit and seed crops. Rep. Rothamsted Exp. Sta. 1953: $167-75$. 
BUTTEL-REEPEN, H. voN

1915. Leben und Wesen der Bienen. Veiweg und Sohn. Braunschweig, Germany. 300 pp.

Camras, S., and P. D. Hurd, JR.

1957. The conopid flies of California (Diptera). Bul. California Insect Surv. 6:19-50.

Caullery, M.

1942. Biologie des Abeilles. Press Univ. France, Paris.

Clausen, C. P.

1940. Entomophagous insects. MeGraw-Hill Book Co., New York, N.Y. 668 pp.

Clements, F. E., and F. L. Long

1923. Experimental pollination. Carnegie Institution of Washington, Washington, D.C. $274 \mathrm{pp}$.

Cockerell, T. D. A.

1893. The entomology of the mid-alpine zone of Custer County, Colorado. Amer. Ent. Soc. Trans. $20: 305-69$.

1896. The bees of the genus Perdita F. Smith. Acad. Nat. Sci. Philadelphia Proc. 48: 25-107.

1923. Two nocturnal bees and a minute Perdita. Amer. Mus. Novitates 66:1-4.

1926. The black bees of Peru. Entomologist 59:28-29.

1933. The excessive abundance of certain bees. Amer. Naturalist 67:1-3.

1936. Materials for a monograph of African bees of the genera Halictus, Ceratina, and Megachile. British Museum. London, England. $254 \mathrm{pp}$.

1937. Bees collected in Arizona and California in the spring of 1937. Amer. Mus. Novitates 948:1-15.

1938. The Western biota. Sci. Monthly 56:433-36.

Cockerell, T. D. A., and W. Porter

1899. Contributions from the New Mexico Biological Station. VII. Observations on bees, with descriptions of new genera and species. Ann. Mag. Nat. Hist. 4: (7) $403-21$.

Crane, M. B., and K. Mather

1943. The natural cross pollination of erop plants with particular reference to the radish. Ann. Applied Biol. 30:301-08.

CUMBER, R. A.

1953. Some aspects of the biology and ecology of bumble-bees bearing upon yields of red-clover seed in New Zealand. New Zealand Jour. Sci. and Technol. (B) 34: $227-40$.

DARWIN, C.

1859. On the origin of species by means of natural selection. John Murray, London, England. $490 \mathrm{pp}$.

Davidion, A.

1895. On the nest and parasites of Prosopis varifrons Cresson. Psyche 7:315-16.

DelPino, F.

1867. Sugli apparecchi della fecondazione nella piante autocarpe. Firenze. $39 \mathrm{pp}$.

DEMOLL, R.

1908. Die Bedeutung der Proterandrie bei Insekten. Zool. Jahrb., Abt. Syst. 26:621-28.

DuCKe, A.

1901. Beobachtungen über Blütenbesuch, Ercheinungszeit etc. der bei Pará vorkommenden Bienen. Ztschr. Syst. Hym. Dipt. 1:25-32, 49-67.

1902. Beobachtungen über Blïtenbesuch, Ercheinungszeit etc. der bei Pará vorkommenden Bienen. Allg. Ztschr. Ent. 7:321-25, 360-67, 400-04, 417-21.

EMLEN, J. T., JR.

1952. Social behavior in nesting cliff swallows. Condor 54:177-99.

ENGEL, E. O.

1929. Notes on two larvae of South African Diptera belonging to the families Leptidae and Asilidae. Royal Soc. So. African Trans. 18:147-62.

FABRE, J. H.

1879-1907. Souvenirs entomologiques. Paris, France. 10 vols.

FARR, S. C.

1886. The humble-bee. New Zealand Country Jour. 10:332-36. 
Ferton, C.

1923. La vie des Abeilles et des Guêpes. Paris, France. 376 pp.

Fisher, R. L.

1953. Native pollinators of alfalfa in northern Minnesota. Minn. Beekeeper 6(3):8-9.

Franklin, W. W.

1952. Wild bees as supplementary pollinators. Amer. Bee Jour. 92:290-91.

FrICK, K. E.

1957. Biology and control of tiger beetles in alkali bee nesting sites. Jour. Econ. Ent. 50:503-04.

FrIEse, H.

1888. Die Smarotzerbienen und ihre Wirte. Zool. Jahrb., Abt. Syst. 3:847-70.

1891. Beitrag zur Biologie der solitärischen Blumenwespen. Zool. Jahrb., Abt., Syst. $5: 751-860$.

1901. Die Bienen Europa's nach ihren Gattungen, Arten und Varietäten auf vergleichend-morphologisch-biologischer Gundlage.

1902. Die arktischen Hymenopteren. Fauna Arctica 5:441-98.

1909. Die Bienen Afrikas nach dem Stande unserer heutigen Kentnisse. Jena. 393 pp.

1923. Die europäischen Bienen. De Gruyter and Company, Berlin and Leipzig, Germany. $466 \mathrm{pp}$.

1935. Apiden aus Nordost-Grönland. Skr. Svalb. Ishavet 65:1-10.

FrISCH, K. voN

1915. Der Farbensinn und Formensinn der Biene. Zool. Jahrb., Abt. Zool. Physiol. $35: 1-182$.

1919. Über den Geruchsinn der Biene und seine blütenbiologische Bedeutung. Zool. Jahrb., Abt. Zool. Physiol. 37:1-238.

1921. Über den Sitz des Geruchsinnes bei Insekten. Zool. Jahrb., Abt. Zool. Physiol. $38: 1-68$.

Frison, T. H.

1922. Notes on the life history, parasites, and inquiline associates of Anthophora abrupta Say, with some comparisons with the habits of certain other Anthophora. Amer. Ent. Soc. Trans. 48:137-56.

Fronk, W. D., and J. A. SLATER

1956. Insect fauna of cucurbit flowers. Kansas Ent. Soc. Jour. 29:141-45.

Frost, S. W.

1943. An observation box for solitary bees and wasps. Jour. Econ. Ent. 36:803-04.

GaBRITSCHEvSKy, E.

1926. Convergence of coloration between American pilose flies and bumblebees (Bom-

Gale, A. bus ). Biol. Bul. 15:269-87; 4 pls.

1905. Enemies of bees. Agr. Gaz. New South Wales 16:489-92.

GCODACRE, W. A.

1923. A casual enemy of the bee, the dragon fly (Heminax papuensis). Agr. Gaz. New South Wales $34: 373-74$.

Graenicher, S.

1905a. On the habits of two ichneumonid parasites of the bee, Ceratina dupla Say. Ent. News 16:43-49.

$1905 b$. Some observations on the life history of parasitic bees. Wisconsin Nat. Hist. Soc. Bul. 3:153-67.

1906a. The habits and life-history of Leucopsis affinis (Say), a parasite of bees. Wisconsin Nat. Hist. Soc. Bul. 4:153-59.

$1906 b$. A contribution to our knowledge of the visual memory of bees. Wisconsin Nat. Hist. Soc. Bul. 4:135-42.

1909. Wisconsin flowers and their pollination. Wisconsin Nat. Hist. Soc. Bul. 7:19-77.

1911. Bees of northwestern Wisconsin. Pubs. Mus. Milwaukee Bul. 1:221-49.

1927. On the biology of bees of the genus Coelioxys (Hymen., Megachilidae). Ent. News 38:231-35, 273-76.

1930. Bee-fauna and vegetation of Miami, Florida. Ent. Soc. Amer. Ann. 23:153-74.

1935. Bee-fauna and vegetation of Wisconsin. Ent. Soc. Amer. Ann. 28:285-310. 
GRANDI, G.

1951. Introduzione allo studio dell'Entomologia. Edizione Agricole [Bologna, Italy]. Vol. 2, $1332 \mathrm{pp}$.

GRANT, V.

1949. Pollination systems as isolating mechanisms in angiosperms. Evolution 3:82-97.

1950. The flower constancy of bees. Botanical Review 16:379-98.

Grassé, P. P.

1942. Les rassemblements de sommeil des Hyménoptères et leur interpretation. Soc.

GRÜTTTE, E.

Ent. France, An. Bul. 1942, pp. 142-48.

1935. Zur Abstammung der Kuckucksbienen. Arch. f. Naturgesch. (n.f.) 4:449-535.

Gubin, A. F.

1945. Bee training for pollination of cucumbers. Bee World 26(5) :34-35.

HAAN, J. H. H. DE

1952. De blauwe houtbij, Xylocopa violacea (L.) Latr. "inheems" te Weert. Natuurh. Maandbl. 41:97-102.

HAMBELTON, J. I.

1944. The role of bees in the production of fruit and seed. Jour. Econ. Ent. 37:522-25.

HARDOUIN, R.

1935. Les moeurs peu connues d'un Tachinaire. Soc. Ent. France Bul. 40:10-11.

1943. Éthologie variable de la Xylocope. Soc. Ent. France Bul. 48:156.

1948. La vie des Abeilles solitaires. 2d ed. Gallimard. Paris, France. 262 pp.

Hawthorn, L. R., G. E. Bohart, and E. H. TOOLE

1956. Carrot seed yield and germination as affected by different levels of insect pollination. Amer. Soc. Hort. Sci. Proc. 67:384-89.

HEINE, E. M.

1937. Observations on the pollination of New Zealand flowering plants. Roy. Soc. New Zealand Trans. $67: 133-48$.

HERBST, P.

1922. Zur Biologie der Gattung Chilicola Spin (Apidae, Hymen.). Entom. Mittei. lungen 11:63-68.

HeRTz, M.

1929. Die Organisation des optischen Feldes bei der Biene, I. Ztschr. vergleich. Physiol. $8: 693-784$.

1939. New experiments in the color vision of bees. Jour. Exp. Biol. 16:1-8.

Hicks, C. H.

1933. Observations on a chrysid parasite and its host (Hymenop.: Chrysididae, Megachilidae). Ent. News 44:206-09.

HILDEBRAND, $F$.

1867. Die Geschlechter-Venteilung bei den Pflanzen und das Gesetz der vermiedenen und unvorteilhaften stetigen Selbstbefruchtung. W. Engelmann. Leipzig. 92 pp.

Hirashima, $\mathrm{Y}$.

1957. Further observations on the life-history and habits of Osmia excavata Alfken (Hymenoptera, Megachilidae). [In Japanese.] Fac. Agr. Kyushu Univ. Sci. Bul. 16:193-202.

HIRsT, S.

1922. Pseudoscorpions and bees. Bee World 4(2):36-37.

Новвs, G. A.

1956. Ecology of the leaf-cutter bee Megachile perihirta Ckil. (Hymenoptera: Megachilidae) in relation to production of alfalfa seed. Canadian Ent. 88:625-31.

1957. Alfalfa and red clover as sources of nectar and pollen for honey, bumble, and leaf cutter bees (Hymenoptera: Apoidea). Canadian Ent. 49:230-35.

HobBs, G. A., and C. E. LILLY

1954. Ecology of species of Megachile Latreille in the mixed prairie region of southern Alberta with special reference to pollination of alfalfa. Ecology 35:453-62.

Новву, В. М.

1931. The British species of Asilidae and their prey. Ent. Soc. So. England Trans. $6: 1-42$. 
HÖPPNER, H.

1904. Zur Biologie der Rubus-bewohner. All. Ztschr. Ent. 9:97-103, 129-34, 161-70. HURD, P. D., JR.

1954. Distributional notes on Eutricharea, a Palearctic subgenus of Megachile, which has become established in the U. S. Ent. News 65:93-95.

1955. The carpenter bees of California (Hymenoptera, Apoidea). California Insect Surv. Bul. 4:35-72.

1956. Notes on the subgenera of the New World carpenter bees of the genus Xylocopa (Hymenoptera, Apoidea). Amer. Mus. Novitates 1776:1-7.

1957. Notes on the autumnal emergence of the vernal desert bee, Hesperapis fulvipes Crawford. Kansas Ent. Soc. Jour. $30: 10$.

1958. The American bees of the genus Dioxys Lepeletier and Serville (Hymenoptera: Megachilidae) Univ. California Pubs. Ent. 14(4):263-90; 28 figs. in text, 4 maps.

HURD, P. D., JR., and C. D. MICHENER

1955. The megachiline bees of California. California Insect Surv. Bul. 3:1-247.

IHERING, H. VON

1905. Biologia das abelhas solitarias do Brazil. Revista Mus. Paulista 6:97-309.

Imms, A. D.

1942. On Braula coeca Nitsch and its affinities. Parasitology 34:88-100.

JACOBS, W.

1924. Das Duftorgan von Apis mellifica und ähnliche Hautdrüsenorgane sozialer und solitärer Apiden. Ztschr. Morph. Ökol. Tiere 3:1-80.

Jamieson, C. A.

1941. A dipterous parasite (Myopa sp.) of the honeybee. Sci. Agr. 21:244.

JANVIER, $\mathrm{H}$.

1933. Étude biologique de quelques Hyménopteres du Chili. Ann. Sci. Nat., Zool. 16 (10) :209-356.

1955. Le nid et la nidification chez quelques abeilles des Andes tropicales. Ann. Sci. Nat. Zool. 17(11):311-49.

JENSEN-HaARUP, A. C.

1907. Biological researches amongst the Argentine bees with special reference to the flowers they visit. Flora og Fauna, pp. 97-107.

1908. Hoffmanseggia falcaria, Cav., and its visitors amongst bees. Flora og Fauna, pp. 108-11.

JöRGENSEN, $\mathrm{P}$.

1909. Beobachtungen über Blumenbesuch, Biologie, Verbreitung usw. der Bienen von Mendoza (Hym.). Deut. Ent. Ztschr., pp. 53-65, 211-27.

1912a. Beitrag zur Biologie einiger südamerikanischer Bienen. Ztschr. wiss. Insektenbiol. 8:268-72.

1912b. Los Crisídidos y los Himenópteros Aculeatos de la Provincia de Mendoza. An. Mus. Nacl. Hist. Nat. Buenos Aires 22:267-338.

Kalmus, H., and C. R. RibBands

1952. The origin of the odours by which honeybees distinguish their companions. Roy. Soc. Proc. (B) 140:50-59.

KELLOGG, C. R.

1941. Some characteristics of the oriental honeybee Apis indica F. in China. Jour. Econ. Ent. 34:717-19.

KERNER, A.

1876. Die Schutzmittel der Blüten gegen unbenefe Gäste. Wein.

KIRSCHER, O. VON

1911. Blumen und Insekten, ihre Anpassungen aneinander und ihre gegenseitige

KNOLL, F.

Abhängigkeit. B. G. Teubner. Leipzig and Berlin, Germany. 436 pp.

1921-26. Insekten und Blumen. Abhandl. Zool.-Bot. Ges., Wien 12:1-645.

KNUTH, P.

1898-99. Handbuch der Blutenbiologie. Wilhelm Engelmann, Leipzig, Germany. 2 vols. 
KöLREUTER, J. G.

1761. Vorläufige Nachricht von einigen das geschlecht der Pflanzen betreffenden Versuchen und Beobachtungen. Leipzig. $263 \mathrm{pp}$.

KREMER, J. C.

1945. Influence of honey bee habits on radish seed yield. Michigan Sta. Quart. Bul. $27: 413-20$.

KRöBER, $\mathrm{O}$.

1919. Katalog der Conopiden, nebst Beschreibung der Gattungen und Bestimmungstabellen der Gattungen und Arten. Arch. Naturgesch. (A) 83:1-52. (1917.)

KÜHN, A.

1927. Über den Farbensinn der Bienen. Ztschr. Vergleich. Physiol. 5:762-800.

KUHN, A., and R. PoHL

1921. Die Dressurfähigkeit der Bienen auf Spektrallinien. Die Naturwissench. 9: $738-40$.

LABERGE, W. E.

1956. A revision of the bees of the genus Melissodes in North and Central America, Parts I and II. Univ. Kansas Sei. Bul. 37(2):911-1194; 38(1):533-78.

LARKIN, R. A.

1952. Wildbee population cycles and the production of alfalfa seed. Agron. Jour. $44: 216-18$.

LECLERCQ, J.

1945. Les Butineurs de l'Hellébore verte. Lambillionea 45:28-29.

LEPPIK, E. E.

1956. The form and function of numeral patterns in flowers. Amer. Jour. Botany $43(7): 445-55$.

1957. Evolutionary relationship between entomophilous plants and anthophilous insects. Evolution 11:466-81.

LEVEque, $\mathrm{N}$.

1932. Some problems in the evolution and taxonomy of carpenter bees (Xylocopidae), correlated with study of their symbiotic mites. Ent. Monthly Mag. 68:109-12.

LiefTINCK, M. A.

1957. De slobkousbij en haar gewoonten. De Levende Natuur 60:121-28.

Linslex, E. G.

1942: Insect food caches as reservoirs and original sources of some stored products pests. Jour. Econ. Ent. 35:434-39.

1943. Notes on the habits of Melecta sierrae Linsley. Pan-Pacific Ent. 19:160.

1944a. Prey of the robber fly Callinicus calcaneus Loew (Diptera, Asilidae). Pan-Pacific Ent. 20:67-68.

1944b. Host relationships of some sapygid wasps (Hymenoptera). Brooklyn Ent. Soc. Bul. 39:54-55.

1944c. Natural sources, habitats, and reservoirs of insects associated with stored food products. Hilgardia 16(4):187-224.

1945. A phorid fly from the nests of Anthophora in California (Diptera). Brooklyn Ent. Soc. Bul. 40:67-68.

1946. Insect pollinators of alfalfa in California. Jour. Econ. Ent. 39:18-29.

LINSLEY, E. G., and J. W. MACSWAIN

1942a. The bionomics of Ptinus californicus, a depredator in the nests of bees. South. California Acad. Sci. Bul. 40:126-37.

1942b. The parasites, predators, and inquiline associates of Anthophora linsleyi. Amer. Midland. Nat. 27:402-17.

1942c. Bionomics of the meloid genus Hornia (Coleoptera). Univ. California Pubs. Ent. $7: 189-206$.

1944. Observations on the life history of Trichodes ornatus (Coleoptera, Cleridae), a larval predator in the nests of bees and wasps. Ent. Soc. Amer. Ann. 36:589601.

1947. Factors influencing the effectiveness of insect pollinators of alfalfa in California. Jour. Econ. Ent. 40:349-57. 
1951. Notes on the biology of Tricrania stansburyi Haldeman (Coleoptera, Meloidae). South. California Acad. Sci. Bul. 50:92-95.

1952a. Notes on the biology and host relationships of some species of Nemognatha (Coleoptera: Meloidae). Wasmann Jour. Biol. 10:91-102.

1952b. Notes on some effects of parasitism on a small population of Diadasia bituberculata (Cresson) (Hymenoptera, Anthophoridae). Pan-Pacific Ent. 28:131-35.

1955. Two new species of Plega from Mexico (Neuroptera, Mantispidae). Pan-Pacific Ent. $31: 15-20$.

1956a. The habits of Nomada opacella Timberlake with notes on other species. Wasmann Jour. Biol. 13:253-76.

$1956 b$. Some observations on the nesting habits and prey of Cerceris californicus Cresson (Hymenoptera, Sphecidae). Ann. Ent. Soc. Amer. 49:71-84.

1956c. Further notes on the taxonomy and biology of the andrenine bees associated with Oenothera. Pan-Pacific Ent. 32:111-21.

1957. Observations on the habits of Stylops pacifica Bohart (Coleoptera, Stylopidae). Univ. California Pubs. Ent. 11:395-430.

1958a. The nesting habits, flower relationships, and parasites of some North American species of Diadasia. Wasmann Jour. Biol. (in press).

$1958 b$. The significance of floral constancy among bees of the genus Diadasia (Hymenoptera, Anthophoridae). Evolution (in press).

$1958 \mathrm{c}$. Sound production among nocturnal bees. Jour. Kansas Ent. Soc. (In press.)

$1958 d$. Sleeping habits of males of Hesperapis. Jour. Kansas Ent. Soc. (In press.)

Linsley, E. G., J. W. MacSwain, and Ray F. Smith

1952a. The bionomics of Diadasia consociata Timberlake and some biological relationships of emphorine and anthophorine bees. Univ. California Pubs. Ent. 9:267-90.

1952b. The life history and development of Rhipiphorus smithi with notes on their phylogenetic significance. Univ. California Pubs. Ent. 9:291-314.

1952c. Outline for ecological life histories of solitary and semi-social bees. Ecology 33:558-67.

1955. Observations on the nesting habits and flower relationships of some species of Meiandrena (Hymenoptera, Andrenidae). Pan-Pacific Ent. 31:173-86.

1956a. Biological observations on Xenoglossa fulva Smith with some generalizations on biological characters of other eucerine bees (Hymenoptera, Anthophoridae). South. Calif. Acad. Sci. Bul. $54: 128-41$.

1956b. Biological observations on Ptilothrix sumichrasti (Cresson) and some related groups of emphorine bees (Hymenoptera, Anthophoridae). South. California Acad. Sci. Bul. 55:83-101.

Linsley, E. G., and C. D. Michener

1939. A generic revision of the North American Nomadidae (Hymenoptera). Amer. Ent. Soc. Trans. $65: 265-305$.

LITH, J. P. VAN

1955. Een nest van Xylocopa violacea (L.). Ent. Bericht. 15:452-54.

1957. On the biology of Chelostoma florisomne (L.) (Apidae, Megachilinae) and its parasite Sapyga clavicornis (L.) (Sapygidae, Sapyginae) (Hymenoptera). Tijdschr. Ent. 100:115-23.

1957a. (= 1957 in $\mathrm{ms}$.)

1957b. On the behavior of Chaetodactylus mites (Acar., Tyr.) in the nests of Osmia rufa L. and Chelostoma florisomne (L.) (Apidae, Megachilidae). Ent. Berichten 17: $197-98$.

LoEW, E.

1884. Beobachtungen über den Blumenbesuch von Insekten an Frielandpflanzen des Botanischen Gartens zu Berlin. Jahrb. Bot. Gart., Berlin 3:69-118.

LøKEN, A.

1949. Insekter som har verdi for pollinering i frukthagen. Saertrykk av Frukt og Baer 2:65-71.

LOTMAR, $\mathrm{R}$.

1933. Neue Untersuchungen über den Farbensinn der Bienen, mit besonderer Berücksichtigung des Ultravioletts. Ztschr. vergleich. Physiol. 19:673-723. 
LOVELL, J. H.

1909-10. The color sense of the honeybee. Amer. Naturalist 43:338-49; 44:673-92.

1913. The origin of the oligotropic habit among bees. Ent. News 24:104-12.

1914. The origin of oligotropism. Ent. News 25:314-21.

1918. The flower and the bee. Charles Seribner's Sons. New York, N.Y. 286 pp.

LUBBOCK, J.

1882. Observations on ants, bees, and wasps. Colors of flowers as an attraction to bees: experiments and considerations thereon. Linn. Soc. London Jour. 16:110-15.

LÜDERWALDT, $\mathrm{H}$.

1910. Zur Biologie zwier brasilianischer Bienen. Ztschr. Wissenschaftliche Ins.-Biol. 6:297-98.

LUDWIG, F.

1900. Über den Blumenbesuch der Apiden in Nordamerika nach den Beobachtungen von Charles Robertson. Allgemeine Ztschr. Ent. 5:307-11.

MacSWaIN, J. W.

1956. A classification of the first instar larvae of the Meloidae (Coleoptera). Univ. California Pubs. Ent. 12:1-182.

1957. The flight period of Martinapis luteicornis (Cockerell) (Hymenoptera: Apoidea). Pan-Pacific Ent. 33:70.

MALYShev, S. I.

1929. The nesting habits of Macropis Pz. (Hymen. Apoidea). Eos 5:97-109.

1930. Nistgewohnheiten der Steinbienen Lithurgus Latr. (Apoidea). Ztschr. Morph. Ökol. Tiere 19:116-34.

1931. Lebensgeschichte der Holzbienen, Xylocopa Latr. (Apoidea).Ztschr. Morph. Ökol. Tiere (A) 23:754-809.

1936. The nesting habits of solitary bees. A comparative study. Eos 11:201-309.

Maneval, $\mathrm{H}$.

1932. Notes recueillies sur les Hymenopteres. Soc. Ent. France Ann. 101:85-110.

MARCHAL, P.

1887. Étude sur l’instinct du Cerceris ornata. Arch. Zool. Exptl. Gén. (2) 5:27-60.

Mathewson, J. A., and H. V. DALY

1955. A brief note on the sleep of male Melissodes (Hymenoptera: Apidae). Kansas Ent. Soc. Jour. 28:120.

MAXWELL-LEFroY, $\mathrm{H}$.

1909. Indian insect life. A manual of the insects of the plains (tropical India). Thacker, Spink, and Co., Calcutta and Simla, India. $786 \mathrm{pp}$.

McInDoo, N. E.

1914. The olfactory sense of the honeybee. Jour. Exp. Zool. 16:265-364.

MEDLER, J. T.

1957. Bumblebee ecology in relation to the pollination of alfalfa and red clover. Insectes Sociaux 4:245-52.

1958. Parasitism of bees in trap-nests by Leucospis affinis Say (Hymenoptera: Leucospidae). Ent. News 69:21-24.

MEIJERE, J. C. H. DE

1903. Beitrag zur kenntnis der biologie und der systematischen verwandtschaft der Conopiden. Tijdschr. voor Ent. 46:144-225.

1912. Neue beitrage zur kenntnis der Conopiden. Tijdschr. voor Ent. 55:184-207.

MELANDER, A. L., and C. T. BRUES

1903. Guests and parasites of the burrowing bee Halictus. Biol. Bul. 5:1-27.

MENKE, H. F.

1952. Alkali bee helps set seed records. What's New in Crops and Soils 4:36-37.

1954. Insect pollination in relation to alfalfa seed production in Washington. Washington Agr. Exp. Sta. Bul. 555. 24 pp.

MiChener, C. D.

1938. American bees of the genus Chelostoma. Pan-Pacific Ent. 14:36-45.

1940. The distributional history of North American bees. Proc. 6th Pacific Sci. Cong. $4: 297-303$. 
1943. The American bees of the genus Anthocopa with notes on Old World subgenera. Ent. Soc. Amer. Ann. 36:49-86.

1944a. Comparative external morphology, phylogeny, and a classification of bees. Amer. Mus. Nat. Hist. Bul. 82:157-326.

1944b. The distribution of the osmiine bees of the deserts of North America. Amer. Naturalist 78:257-66.

1947a. Some observations on Lasioglossum (Hemihalictus) lustrans (Hymenoptera, Halictidae). New York Ent. Soc. Jour. 55:49-50.

1947b. Bees of a limited area in southern Mississippi. Amer. Midland Nat. 38:443-55.

1951a. Records and descriptions of megachilid bees from Texas. Pan-Pacific Ent. 27: $61-71$.

1951b. In: Muesebeck, Krombein and Townes, Hymenoptera of America north of Mexico - Synoptic Catalogue. U. S. Dept. Agr. Monog. 2. 1420 pp.

1953a. Life-history studies in insect systematics. Systematic Zool. 2:112-18.

$1953 b$. The biology of a leafcutter beet (Megachile brevis) and its associates. University Kansas Sci. Bul. 35:1569-1784.

1954. Bees of Panamá. Amer. Mus. Nat. Hist. Bul. 104:1-176.

1955a. Some biological observations on Hoplitis pilosifrons and Stelis lateralis (Hymenoptera, Megachilidae). Jour. Kansas Ent. Soc. 28:81-87.

1955b. Apoidea, in: A century of progress in the natural sciences. California Acad. Sci., San Francisco. 807 pp.

Michener, C. D., E. A. Cross, H. V. Daly, C. W. Rettenmeyer, and A. Wille

1955. Additional techniques for studying the behavior of wild bees. Insectes Sociaux 2:237-46.

Michener, C. D., and Rudolf B. LANGe

1957. Observations on the ethology of some Brazilian colletid bees (Hymenoptera, Apoidea). Jour. Kansas Ent. Soc. 30:71-80.

MiChener, C. D., and C. W. RETTEN MEYER

1956. The ethology of Andrena erythronii with comparative data on other species (Hymenoptera, Andrenidae). Univ. Kansas Sci. Bul. 37:645-84.

Michener, C. D., and R. R. SOKAL

1957. A quantitative approach to a problem in classification. Evolution 11:130-62.

MILLER, A. H.

1951. An analysis of the distribution of the birds of California. Univ. California Pubs. Zoöl. 50:531-64.

MilleR, N. C. E.

1956. The biology of the Heteroptera. Leonard Hill Ltd., London. $162 \mathrm{pp}$.

MONTGOMERY, B. E.

1951. The status of bumble bees in relation to pollination of red clover in New Zealand.

MOURE, J. S. Proc. 6th Ann. Meetings No. Central State Br., Amer. Assn. Econ. Ent., pp. 51-55.

1943. Abelhas de batatais (Hym. Apoidea). Arquiv. Museu Paranense 3:145-203.

OLBERG, G.

1953. Der Bienenfeind Philanthus (Bienenwolf). Geest and Portig, Leipzig. $78 \mathrm{pp.}$

Moure, J. S., and C. D. Michener

1955. The bee family Fideliidae in South America (Hymenopt.-Apoidea). Dusenia 6:199-206.

Muesebeck, C. F. W., K. V. Krombein, and H. K. Townes

1951. Hymenoptera of America north of Mexico-Synoptic Catalogue. U. S. Dept. Agr Monograph $2.1420 \mathrm{pp}$.

MÜLLER, $\mathrm{H}$.

1873. Die Befruchtung der Blumen durch Insekten und die gegenseitigen anpassung Beider. Wilhelm Engelmann. Leipzig, Germany. 478 pp.

MÜLLER, W. H.

1882. Proterandrie der Bienen. Leignitz, Germany. 45 pp.

NEILSEN, E. T.

1934. Sur les habitudes des hyménoptères aculéates solitaires, IV (Apidae). Ent. Meddel. 18:421-72. 
NishIDA, T.

1958. Pollination of the passion fruit in Hawaii. Jour. Econ. Ent. 51 (2) :146-49.

PACKARD, A. S.

1865. The humble bees of New England and their parasites. Proc. Essex Inst. 4:107-20.

PAINTER, R. H.

1932. The Bombyliidae of China and nearby regions. Lingnan Sci. Jour. 11:341-74.

PARK, O. W.

1922. Time and labor factors involved in gathering pollen and nectar. Amer. Bee Jour. $62: 254-55$.

PA'T', V. S. L.

1947. Neotropical Sapygidae, with a conspectus of the family (Hymenoptera: Aculeata). Acta Zool. Lilloana 4:393-426.

Pearson, J. F. W.

1933. Studies on the ecological relations of bees in the Chicago region, Ecol. Monograph 3:375-441.

PECK, O., and J. L. BoLtoN

1946. Alfalfa seed production in northern Saskatchewan as affected by bees, with a report on means of increasing populations of native bees. Sci. Agr. 26:388-418.

Percival, M.

1947. Pollen collection by Apis mellifera. New Phytol. 46:142-73.

1950. Pollen presentation and pollen collection. New Phytol. 49:40-63.

PÉREZ, J.

1886. Des effets du parasitisme des Stylops sur les apiaires du genre Andrena. Actes Soc. Linnéenne Bordeaux 40:21-60.

1889. Les Abeilles. Hachette et Cie, Paris, France. 344 pp.

Perkins, R. C. L.

1918. Further notes on Stylops and stylopized bees. Ent. Mo. Mag. 54:67-76.

1919. The British species of Andrena and Nomada. Ent. Soc. London Trans. pp. 218319.

Petersen, H. L.

1954. Pollination and seed setting in lucerne. Årsskrift. Kgl. Vet.-og Landbohøjskole, pp. 138-69.

Philip, G. L., and G. H. VANsell

1932. Pollination of deciduous fruits by bees. California Agr. Exp. Sta. Cir. 62:1-27. Phillips, E. F.

1933. Insects collected on apple blossoms in western New York. Jour. Agr. Research 46:851-62.

Pierce, W. D.

1909. A monographic revision of the twisted winged insects comprising the order Strepsiptera Kirby. U. S. Natl. Mus. Bul. no. 66. 232 pp.

Piper, C. V., W. M. Evans, R. MCKeE, and W. J. Morse

1914. Alfalfa seed production; pollination studies. U. S. Dept. Agr. Bul. no. 75.32 pp.

Plateau, F.

1877. L'instinct des insectes peut-il être mis en défaut par les fleurs artificielles? Assoc. Français avanc. Sci., pp. 1-6.

1895. Comment les fleurs attirent les insectes. Researches expérimentales. Acad. Roy. Belgique Bul. 31:466-88.

1897. Comment les fleurs attirent les insectes. Researches expérimentales. V. Acad. Roy. Belgique Bul. 34:847-80.

1901. Observations sur le phénomène de la constance chez quelques hyménoptères. Ann. Soc. Ent. Belgique 45:56-83.

1902. Observations sur les erreurs comises par les hyménoptères visitant les fleurs. Ann. Soc. Ent. Belgique, 46:113-129.

1907. Les insectes et la couleur des fleurs. Année Psychol. 13:67-79.

Plath, O. E.

1925. The rôle of bumblebees in the pollination of certain cultivated crops. Amer. Naturalist 59:441-51.

1934. Bumblebees and their ways. Macmillan Co., New York. 201 pp. 
Popov, V. V.

1951a. Geographical distribution and evolution of the Apidae of the genus Clisodon Patton (Hymenoptera, Anthophoridae). [In Russian.] Zool. Zhur. 30:243-52.

1951b. On the significance of Apidae (Hymenoptera, Apoidea) in the pollination of alfalfa. [In Russian.] Trud. Vseoyuz. Ent. Obshch. 43:65-82.

1952a. Apidae as pollinators of Chenopodiaceae. [In Russian.] Zool. Zhur. 31:494-503.

1952b. Hymenoptera, Apoidea of S. W. Turkmenistan and their ecological distribution. [In Russian.] Trud. Zool. Inst. Acad. Nauk SSSR 10:61-117.

1952c. Bee fauna and its distribution in the central part of the state forest region at Mt. Vishnevaya-Caspian Sea. [In Russian.] Trud. Zool. Inst. Acad. Nauk SSSR 11:142-65.

1953. On the reduction of the sting apparatus of Dioxinae, the parasitic subfamily of Hymenoptera, Megachilidae. [In Russian.] Trud. Zool. Inst. Acad. Nauk. SSSR 13:337-51.

1956. Bees, their relations to melitophilous plants and the problem of the alfalfa pollination. [In Russian w. English summary.] Rev. Ent. URSS 35:582-98.

Poulton, E. B.

1924. The relation between the larvae of the asilid genus Hyperechia (Laphriinae) and those of xylocopid bees. Ent. Soc. London Trans. pp. 121-123.

P $̈$ L, L. VAN DER

1954. Xylocopa and flowers in the tropics. I. The bees as pollinators. Lists of flowers visited. Proc. Akad. Wet. Amsterdam (C) 57:413-23.

RAU, P.

1916. The sleep of insects; an ecological study. Ent. Soc. Amer. Ann. 9:227-74.

1922. Ecological and behavior notes on Missouri insects. Acad. Sci. St. Louis Trans. $24: 1-71$.

1928. The nesting of the little carpenter bee, Ceratina calcarata. Ent. Soc. Amer. Ann. $21: 380-96$.

1933. The jungle bees and wasps of Barro Colorado Island. Phil Rau. Kirkwood, Mo. $324 \mathrm{pp}$.

1935. Notes on the nesting habits of the red-bellied bee, Andrena erythrogastra Ash. Ent. News $46: 35-37$.

RAYMENT, T.

1935. A cluster of bees. Endeavour Press. Sydney, Australia. 752 pp.

1954a. Incidence of acarid mites on the biology of bees. Australian Zool. 12:26-38.

1954b. Remarkable bees from a rain forest. Australian Zool. 12:46-56.

RÉAumur, R. A. F. DE

1734-42. Mémoires pour servir à l'histoire des Insectes. Imprim. Royale. Paris, France. 6 vols.

REINHARD, E. G.

1924. The life history and habits of the solitary wasp, Philanthus gibbosus. Smithsonian Inst. Ann. Rept. (1922), pp. 363-76.

RICHARDS, O. W.

1949. The evolution of cuckoo bees and wasps. Linnaean Soc. London Proc. 161:40-41.

ROBERTSON, C.

1888. Effect of wind on bees and flowers. Botanical Gaz. 13:33-34.

1899. Flower visits of oligotropic bees. Botanical Gaz. $28: 215$.

1902. Synopsis of Andreninae. Amer. Ent. Soc. Trans. 28:187-94.

1914. Origin of oligotropy of bees. Ent. News 25:67-73.

1918. Proterandry and flight of bees. Ent. News $29: 340-42$.

1922. Synopsis of Panurgidae (Hymenoptera). Psyche 29:159-73.

1925. Heterotropic bees. Ecology 6:412-36.

1926. Phenology of inquiline and nest-making bees. Psyche 33:116-20.

1928. Flowers and insects. List of visitors of 453 flowers. Carlinville, Illinois. $221 \mathrm{pp}$.

1929. Phenology of oligolectic bees and favorite flowers. Psyche 36:112-18.

1930. Proterandry and flight of bees (Hymen.: Apoidea). Second paper. Ent. News 41:154-57, 331-36. 
RoNNA, A.

1937. Melaloncha ronnai Brgm. 1935 (Phoridae) endoparasita de Apis mellifica L. Rev. Indus. Anim. 4:113-16.

ROZEN, J. G.

1958. Monographic study of the genus Nomadopsis Ashmead (Hymenoptera: Andrenidae). Univ. California Pubs. Ent. (in press).

Ruiz Perez, F.

1942. Notos biologicas de algunos generos de abejas solitarias de Chile. Bol. Sanidad Vegetal 2:8-16.

SALT, G.

1927. The effect of stylopization on Aculeate Hymenoptera. Jour. Exp. Zool. 48:223331.

1929. A contribution to the ethology of the Meliponinae. Ent. Soc. London Trans. 77: 431-70, pls. 20-24.

1931. A further study of the effect of stylopization on wasps. Jour. Exp. Zool. 59: 133-66.

SCHRotrky, C.

1901. Biologischen Notizen solitärer Bienen von S. Paulo (Brazilien). Allgemeine Ztschr. Ent. 6:209-16.

1907. A contribution to the knowledge of some South American Hymenoptera, chiefly from Paraguay. With notes by T. D. A. Cockerell. Smithsonian Misc. Coll. 48: 259-74.

1908. Blumen und Insekten in Paraguay. Ztschr. wiss. Insektenbiol. 4:22-26, 47-52, $73-78$.

1909. Blumen und Insekten in Paraguay. II. Ztschr. wiss. Insektenbiol. 5:205-14, 277-80.

SCHWARZ, E. A.

1901. Sleeping trees of Hymenoptera. Ent. Soc. Washington Proc. 4:24-26.

ScHWARZ, H. F.

1934. The solitary bees of Barro Colorado Island, Canal Zone. Amer. Mus. Novitates 722:1-24.

1948. Stingless bees (Meliponidae) of the Western Hemisphere. Amer. Mus. Nat. Hist. Bul. $90: 1-546$.

SEgur, E.

1930. Un nouveau parasite de l'abeille domestique. Encycl. Ent., B II, Diptera 5:169-70.

SElander, R. B., and G. E. BoharT

1954. The biology of Zonitis atripennis flavida LeConte (Coleoptera: Meloidae). Wasmann Jour. Biol. 12:227-43.

SEVERIN, H. C.

1937. Zodion fulvifrons Say (Diptera: Conopidae), a parasite of the honey bee. Ent. News 48:243-44.

SHELFORD, R.

1902. Observations on some mimetic insects and spiders from Borneo and Singapore. Zool. Soc. London Proc. 1902 (2) :230-84.

SHorikov, A. S.

- 1936. Present state of the problem of the pollination of cultivated crops by insects. [In Russian.] Trav. Inst. Zool. Acad. Sci. URSS, pp. 1-70.

1937. Die grönländischen Hummeln im Aspekte der Zirkumpolarfauna. Ent. Meddel. 20:37-64.

Simintzis, G., and S. Fiasson

1951. Apimyiasis in Frankreich. Rev. Med. Vet. 102:351-61.

SKaIFE, S. H.

1921. A tachinid parasite of the honey bee. So. African Jour. Sci. 17:196-200.

1952. The yellow-banded carpenter bee, Mesotrichia caffra Linn., and its symbiotic mite, Dinogamasus braunsi Vitzhun. Ent. Soc. So. Africa Jour. 15:63-76.

Sladen, F. W. L.

1919. Wasps and bees. Rept. Canadian Arctic Exped. 3:25g-38g. 
SMITH, F.

1853-58. Catalogue of Hymenopterous Insects. British Museum (Natural History), London, England. 7 vols.

SMITH, G., and A. H. HAMM

1914. Studies in the experimental analysis of sex. Pt. II. On Stylops and stylopization. Quart. Jour. Microseop. Sei. 60:435-61.

SPRENGEL, C. K.

1793. Das Entdecke Geheimniss der Natur im Bau und in der Befruchtung der Blumen. Friedrich Vieweg. Berlin, Germany. $444 \mathrm{pp}$.

STEPhen, W. P.

1955. Alfalfa pollination in Manitoba. Jour. Econ. Ent. 48:453-58.

1958. [Nomia melanderi in Oregon.] Oregon Ent. Soc. Bul. 15(3):3.

STEVENS, O. A.

1920. Notes on species of Halictus visiting evening flowers (Hym.). Ent. News 31: $35-44$.

1948. Native bees. North Dakota Agr. Exp. Sta. Bimonthly Bul. 10:187-94.

TANIGUCHI, $\mathrm{S}$.

1954. Biological studies on Japanese bees I. Comparative study of glossa. Sci. Repts. Hyogo Univ. Agr., Ser. Agr. Biol. 1:81-89.

1956. Biological studies on Japanese bees. III. Request in flower-visiting of infrasocial bees. Sci. Repts. Hyogo Univ. Agr., Ser. Agr. Biol. 2:37-51.

THIEM, $\mathrm{H}$.

1935. Der Bienenwolf, ein gefahrlicher Bienenschadling. Kranke Pflanze 12:112-15.

THIES, S. A.

1953. Agents concerned with natural crossing of cotton in Oklahoma. Agron. Jour. 45 (10): :481-84.

Thоmson, G. M.

1927. The pollination of New Zealand flowers by birds and insects. Proc. New Zealand Inst. Trans. 57:106-25.

Timberlake, P. H.

1954. A revisional study of the bees of the genus Perdita F. Smith, with special reference to the fauna of the Pacific Coast (Hymenoptera, Apoidea) Part I. Univ. California Pubs. Ent. 9:345-432.

1956. A revisional study of the bees of the genus Perdita F. Smith, with special reference to the fauna of the Pacific Coast (Hymenoptera, Apoidea) Part II. Univ. California Pubs. Ent. 10:247-350.

Timberlake, P. H., and C. D. Michener

1950. The bees of the genus Proteriades (Hymenoptera, Megachilidae). Univ. Kansas Sci. Bul. 33:387-440.

Toumanoff, C.

1930. Les maladies des abeilles. Vigot Frères, Paris, France.

1939. Les ennemis des abeilles. Hanoi, Indo-China. $178 \mathrm{pp}$.

ULRICH, W.

1933. Fang und Züchtung von Strepsipteren. Hanb. Biol. Arb. (9) 7:259-327.

USINGER, R. L.

1958. Harwanzen or "resin bugs" in Thailand. Pan-Pacific Ent. 34:52-53.

VIERECK, H. L.

1916. Guide to the insects of Connecticut. Part III, the Hymenoptera, or wasp-like insects, of Connecticut. Conn. Geol. Nat. Hist. Surv., Bul. 22. 824 pp.

VITKovsKx, $\mathrm{N}$.

1914. Les libellules enemies des abeilles. L'Abeille (Russe). Ekaterinoslav. No. 10. 4 pp. Vitzhum, H. G.

1930. Acarologische Beobachtungen (14. Reihe.). Zoologische Jahrb., Abt. Syst. Ökol. Geogr. Tiere 59:281-350.

Vivino, A. E., and L. S. Palmer

1944. The chemical composition and nutritional value of pollens collected by bees. Arch. Biochem. 4(2):129-36. 
VLeugel, D. A.

1947. Waarnemingen aan het gedrag van de Grijze Graafbei (Andrena vaga Panz.) (Hym.). Ent. Berichten 12:185-92.

1952. Beobachtungen über den Revierbesitz bei der roten mauerbiene (Osmia rufa L.). Trans. 9th Int. Congr. Ent. Amsterdam 1951; 1:402-08.

WERCKMEISTER, $\mathrm{P}$.

1951. Die blaue Holzbiene als Bestäuber. Natur. u. Volk 81:116-20.

WERY, J.

1904. Quelques expériences sur l'attraction des abeilles par les fleurs. Acad. Belgique Cl. Sci. Bul. $1904: 1211-61$.

WHEELER, W. M.

1910. Effects of parasitic and other kinds of castration on insects. Jour. Exptl. Zool. $8: 377-438$.

1919. The parasitic Aculeata, a study in evolution. Amer. Philos. Soc. Proc. 58:1-41. Williams, F. X.

1927. Notes on the habits of the bees and wasps of the Hawaiian Islands. Hawaiian Ent. Soc. Proc. 6:425-64.

WoLF, E.

1937. Flicker and the reactions of bees to flowers. Jour. Gen. Physiol. 20:511-18.

WRIGHT, M.

1944. Some random observations on dragonfly habits, with notes on their predaceousness on bees. Tennessee Acad. Sci. Jour. 19:295-301.

WYKES, G. R.

1952. The preference of honeybees for solutions of various sugars which occur in nectar. Jour. Exp. Biol. $29: 511-19$.

ZETTERSTEDT, J. W.

1838. Insecta Lapponica descripta. Voss. Leipzig, Germany. 1139 pp. 

The journal Hilgardia is published at irregular intervals in volumes of about 600 pages. The number of issues per volume varies.

Subscriptions are not sold. The periodical is sent as published only to libraries, or to institutions in foreign countries having publications to offer in exchange.

You may obtain a single copy of any issue free, as long as the supply lasts; please request by volume and issue number from:

Agricultural Publications

Room 22, Giannini Hall

University of California

Berkeley 4, California

The limit to nonresidents of California is 10 separate issues on a single order. A list of the issues still available will be sent on request. 


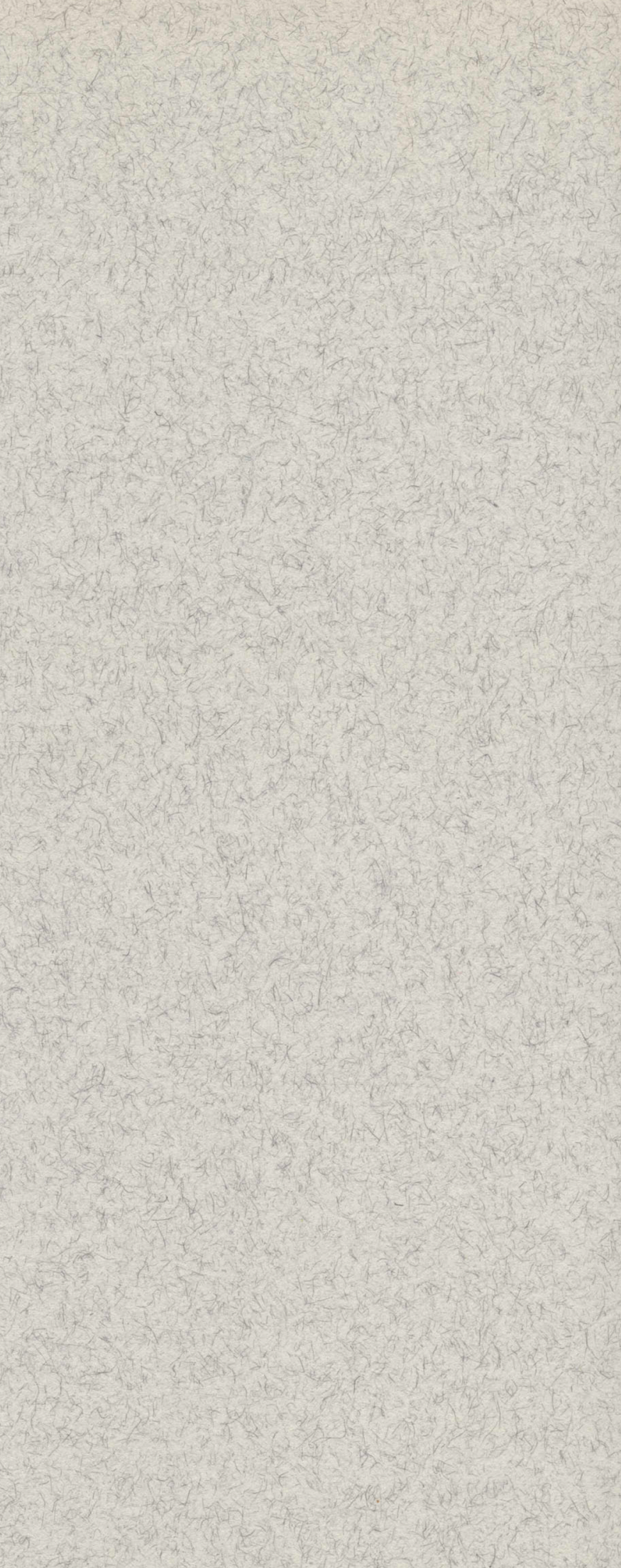

